\title{
Mutluluk Kavramının Felsefi, Psikolojik ve Dini Açıdan İncelenmesi
}

\author{
Examining the Phenomenon of Happiness in the Context of Religiosity Essence
}

\section{Fatma Baynal $^{*}$ (1)}

Öz

Bu araştırmada mutluluk kavramı incelenecektir. Bu doğrultuda, mutluluk kavramının felsefi, psikolojik ve dini açıdan nasıl değerlendirildiği üzerinde durulmuştur. Din ve dindarlık faktörünün mutluluk üzerinde ne gibi etkisi olduğu araştırılmıştır. Ampirik araştırmalarda mutluluk kavramının yaşam doyumu, iyi oluş, yaşam memnuniyeti gibi farklı tanımlamalar ile ele alındığı tespit edilmiştir. Felsefede eudaimonik ve hedonik açıdan ele alınan mutluluk anlayışının psikolojik düşünceye de yansıdığı ortaya çıkmıştır. Bununla birlikte psikolojide mutluluk anlayışının dönemsel açıdan değişikliğe uğradığı görülmüştür. Araştırma sonuçlarında kişinin mutlu olmasında inancın ve erdemli davranışların önemi ortaya çıkmıştır. Dini açıdan mutluluğun insanın nihai amacı veya arayışı olup olmadığı tartışımıştır. Bireylerde mutlulukla ilgili dini ve dünyevi algının incelenmesi konusunda önerilerde bulunulmuştur.

\section{Anahtar Kelimeler}

Felsefe, Psikoloji, Din, Din Psikolojisi, Mutluluk, Dindarlık

\begin{abstract}
In this research, the concept of happiness will be examined in the context of religion. In this direction, it is focused on how the concept of happiness is evaluated philosophically, psychologically and religiously. It has been researched what effect religion and religiosity factor has on happiness. In empirical researches, it was determined that the concept of happiness was handled with different definitions such as life satisfaction, well-being and life satisfaction. It was revealed that the concept of happiness in philosophy, which is discussed in terms of eudaimonically and hedonically is also reflected in psychological thought. However, it has been observed that the mentality in psychology has changed periodically. In the results of the research, the importance of belief and virtuous behaviors have emerged in making the person happy. Whether or not happiness is the ultimate purpose or quest of man is discussed from a religious perspective. Suggestions have been made to examine individuals' religious and secular perception of happiness.
\end{abstract}

\section{Keywords}

Philosophy, Psychology, Religion, Psychology of Religion, Happiness, Religiosity

\footnotetext{
* Sorumlu Yazar: Fatma Baynal (Dr. Öğr. Üyesi), Yalova Üniversitesi, İslami İlimler Fakültesi, Din Felsefesi Bölümü, Yalova, Türkiye. E-posta: fatmayogurtcu@gmail.com ORCID: 0000-0002-6705-4340 


\section{Extended Summary}

Happiness is one of the strongest emotions that motivate people; it is effective in the design of individuals' lives. Therefore, its philosophy is among the priority issues in psychological and religious fields. This research will examine the concept of happiness, focusing on how the concept is assessed from a philosophy, psychological and religious perspective. Literature on religion, religiosity and happiness will also be analyzed and the relevant approaches will be discussed with amprique findings. In philosophy, the source of happiness has been researched. In general, philosophers handled happiness in terms of pleasure and virtue.

Happiness is in the hedonist philosophy is about fulfilling persons' physical, intellectual or social needs. In the eudaimonic philosophy, it is about the individual to realize themselves and sustain a meaningful life. ${ }^{1}$ According to the opinion of the Islamic philosophers whom are close to the eudaimonic philosophy, in the other world people will finally get the happiness which is the highest good and purpose. ${ }^{2}$ The concept of happiness, which represents everything that is good in psychology, can be expressed in different words, such as well-being or quality of life. ${ }^{3}$ The hedonic approach, often describes happiness as a pleasure or avoidance of pain, the eudaimonic approach focuses on meaning and self-realization for happiness in psychology. ${ }^{4}$ In the early days, negative emotions such as depression and anxiety were emphasizes, but with the emergence of positive psychology also emerging, positive emotions have been highlighted over time. ${ }^{5}$ It has recently been the focus that forcing people to be happy makes them more unhappy. So there are different views that striving to exaggerate suffering and be constantly happy has led to an increase in unhappiness. ${ }^{6}$ The religions were intertwined in the psychosocial, economic, political, biological and physical aspects of life. ${ }^{7}$ It therefore transforms the believer from an sense, thinking and behavior. It also brings meaning and purpose to a person's life and a certain sense of identity. ${ }^{8}$ Religion can have a positive impact on

1 Alan S, Waterman, "Two Conceptions of Happiness: Contrasts of Personal Expressiveness (Eudaimonia) and Hedonic Enjoyment”. J. Pers. Soc. Psychol. 64, (1993): 679-680.

2 Bircan, "İslam Ahlak Felsefesi," 422,425.

3 Ruut Veenhoven, "Happiness: Also known as 'Life- Satisfaction' and 'Subjective Well-Being'”, In Handbook of Social Indicators and Quality of Life Research. Eds. Kenneth C. Land, Alex C. Michalos, and M. Joseph Sirgy. Dordrecht, Netherlands: Springer Publishers, (2012): 1-2.

4 Richard Ryan and Edward Deci, "On Happiness and Human Potentials: A Review Of Researchon Hedonic and Eudaimonic Well-Being”, Annu. Rev. Psychology, 52, (2001): 141.

5 İlker Kaba, Murat Erol ve Kadir Güç, "Yetişkin Yaşam Doyumu Ölçeğinin Geliştirilmesi”, Anadolu Üniversitesi Sosyal Bilimler Dergisi, (2017): 2.

6 Sebile Başok Diş, “Bir Dayatma Halini Alan Mutluluk Talebi”, Temaşa, 8, (2018), 27-31.

7 Neda Armaner, Din Psikolojisine Giriş (Ankara: Ayyıldız Matbaası, 1980), 71.

8 Asım Yapıcı, Ruh Să̆llğg ve Din (Adana: Karahan yayınları. 2007), 19. 
the happiness of individuals through negative experiences, dealing with fears, feeling of intent and fulfilling the need for a family. ${ }^{9}$

Islam signals the weaknesses of the religious person's self; it places orders to be forgiving, fair, humble from social relations and encourages the person to be spiritual happy. ${ }^{10}$ It gives people a plan of life, just like other religions. It is promised that people living in this plan will be happy in this world and the other world. ${ }^{11}$ While knowledge and hikmet are essential for the person to achieve happiness according to Islamic ethics, it is only possible to achieve happiness through senior behavior. ${ }^{12}$ Contrary to the efforts of the modern age to achieve happiness, religion advises people that one cannot be happy with beings in this world; it states that people who turn to materiality to be happy will be more unhappy.

Mystical teaches are also mentioned that they are leading people to happiness. ${ }^{13}$ Emotions like love, affection, closeness and compassion that exist in one's soul will bring joy to the individual. ${ }^{14}$ Unhappiness is more about people's thoughts than a situation. Therefore, the individual needs to try to stay true rather than have been fabricated in his mind. ${ }^{15}$ It is aimed a person to know oneself and control their practices in Sufism too. ${ }^{16}$ The person who knows himself can do his/her best to seek happiness in assets other than himself. ${ }^{17}$

Recently, in psychology, instead of striving to be happy, it has been mentioned that the person turns to himself and the virtues. However, in religion, we can mention that happiness is not a search or a goal like in psychology, and there is no temporal or situational limit to happiness. The fact that the religion's understanding of happiness is not

9 Özlem Yorulmaz, "Relationship Between Religiosity and Happiness in Turkey: Are Religious People Happier?” Çankırı Karatekin Üniversitesi İktisadi ve İdari Bilimler Fakültesi Dergisi, 6/1, (2016), 813.

10 T.A. Baasher, “İslam and Mental Health”, Eastern Mediterranean Health Journal, 7/3, (2001): 374.

11 Taner Cücü, İslam'da Mutluluk Prensibi (İstanbul: Otağ Yayınları, 1978), 249.

12 Murat Demirkol,’’̇slam Ahlak Düşüncesinin Gelişiminde Filozofların Katkısı”,Eskiyeni 28, (2014): 83-84.

13 Albrecht Classen, "Mystical Visions and Spiritual Health -Medieval Mysticism as a Platform For The Exploraton of Human Spirituality and Happiness," Studies in Spirituality, 25, (2015): 138 ;

14 Dalai Lama, and Howard C. Cutler, M.D., Mutluluk Sanatı (İstanbul: Dharma Yayınları, 2000), $63,66$.

15 Echart Tolle, A New Earth Awakening is Your Lifes Purpose (Usa: Penguin Group, 2008), 59.

16 Lynn Wilcox, Sufism and Psychology, (Chicago: Abjad Book Designers \& Builders,1995), 3,206 .

17 Erol Güngör, İslam Tasavvufunun Meseleleri (İstanbul: Ötüken Yayınları), 17. 
dependent on any condition can free a person from everything, including the expectation of reward in the afterlife.

As a result, knowing oneself is a common feature of being happy in terms of religious, mystical and even some contemporary psychology studies. Being conscious of one's existence can naturally lead him to virtuous behavior as he attains true happiness. A person who realizes that everything that exists in this life is destined to disappear may turn to himself instead of focusing on temporary happiness or unhappiness. This work aims to shed light on the nature of the happiness presented as the final value the individual wants to achieve today and will contribute to the area through the results. In further research, we are looking at the religious and religious perception of happiness in individuals. 


\section{Giriş}

Aristoteles'ten Farabi'ye, Kant'tan Fromm'a kadar filozofların ve psikologların ortak konusu olan mutluluk, günümüzde de ele alınmaya devam etmektedir. Her bireyin arzu ettiği ve erişmek istediği bir duygu olan mutluluğun mahiyetine dair farklı görüşler vardır. Mutluluk ile ilgili yapılan tanımlarda bireysel veya dış etkenler üzerinde durulmaktadır. Bu tanımlamalara göre mutlu olmak için olumlu düşünceden, insan ilişkilerine, ekonomik koşullardan dindarlığa kadar geniş bir yelpaze söz konusudur.

Felsefede, mutluluğun kaynağının ne olduğu araştırılmış; insanların nasıl mutlu olacağı ile ilgili çeşitli görüşler ortaya konulmuştur. Psikolojide ilk zamanlar insanı neyin mutsuz ettiği üzerinde durulmuş, günümüzde ise bireyin mutlu olması için çeşitli yöntemler ele alınmaya başlanmıştır. Dinler insanoğlunun mutluluk arayışında daima merkezi bir konuma sahip olmuştur. Ancak bazı araştırmacılara göre dinler, insanları mutlu olmasını sağlarken bazıları için çok acı ve şiddetin kaynağı olarak görmüştür. Freud'a göre din, insanlara cinsellik ile ilgili kısıtlamalar getirerek onların mutlu olmasını engellemiştir. Dinler, mutluluğun ancak kişi din yoluna yöneldiğinde elde edileceğini ve acıdan korunulacağını vaat ederek dünyevi olan şeylerin değerini düşürmüştür. ${ }^{18}$ Fromm'a göre ise bir dinden veya başka bir olgudan kaynaklanan inancımız sayesinde umutsuzluklarımızı aşabilir ve kendimizi gerçekleştirebiliriz. ${ }^{19}$ Din ile ilgili bu yorumlara benzer görüş farklılıkları olmakla birlikte din, dindarlık ve mutluluk popüler araştırma konuları arasında yer almaya devam etmektedir.

Modern toplumda gelişen bilim ve teknoloji ile birlikte insanın mutluluğunun da doğru orantılı olarak arttığı söylenememektedir. ${ }^{20}$ Hatta depresyon gibi psikolojik rahatsızlıklar günümüzde en fazla görülen hastalıklar arasında yer almakla birlikte küresel hastalık yükünün önde gelen nedenleri arasında olmaya devam edeceği öngörülmektedir. ${ }^{21}$ Mutlu olma gereğinin telkin edilmesi, kişinin sürekli beklenti hali içerisinde yaşayan ve mutlu olmak için sürekli çabalayan bir varlığa dönüşmesine neden olabilmektedir. Bu durum, kişiyi mutluluk arayışı döngüsüne sürükleyebileceği gibi bireyin, onu elde etmek için ahlak dışı eylemlere yönelmesine neden olabilir. $\mathrm{Bu}$ nedenle zihinlerdeki mutluluk anlayışını sorgulamak hem bireysel hem de toplumsal açıdan daha doğru bir yaşam olanağı ile insanların birbirlerine daha hakkâniyetli

18 Sigmund Freud, Uygarlık, Din ve Toplum (Ankara: Öteki yayınevi, 1995), 32,35.

19 Erich Fromm, Erdem ve Mutluluk, Çeviren Ayda Yörükan (Ankara: İş Bankası Yayınları, 1995), 227-229.

20 Alexis Carrel. İnsan Denen Meçhul (İstanbul: Hayat Yayınları,1997), 115.

21 WHO, "World Mental Health Day: Depression: A Global Crisis," (Geneva: World Health Organization, 2012): 2. 
davranması açısından önemlidir. Buna göre mutluluğun hazza indirgendiği, mutlu olmanın amaçsallaştırıldığı ancak daha da uzak bir ütopyaya dönüştügü günümüzde felsefi, psikolojik ve dini açıdan mutluluğun gerçek mahiyetini anlamanın önemi ortaya çıkmaktadır.

$\mathrm{Bu}$ araştırma ile tarihsel süreç içerisinde filozofların ve psikologların mutluluk ile ilgili görüşleri ele alınacaktır. Ayrıca din, dindarlık ve mutluluğa dair literatür analiz edilecek ve konuyla ilgili yaklaşımlar amprik bulgularla desteklenerek tartış1lacaktır. Günümüzde bireyin ulaşmak istediği nihai değer olarak sunulan mutluluğun mahiyetine 1şık tutmayı amaçlayan bu çalışma ulaştı̆̆ sonuçlarla alana katkı sağlayacaktır.

\section{Felsefede Mutluluk}

Felsefi akımlardan günümüz psikoloji ekollerine kadar ayrıntılı bir şekilde incelenen mutluluk, her bireyin aradığı, ulaşmak istediği ve hayatını bu duyguya göre şekillendirdiği bir olgu olarak karşımıza çıkmaktadır.

Mutluluk düşüncesinin tarihsel açıdan seyrine bakacak olursak önde gelen filozofların mutluluk ile ilgili yorumları karşımıza çıkmaktadır. Antik Yunan düşünürü Sokrates (MÖ 399) kişinin kendisiyle uyumlu olmasını sağlayan erdemli ve bilge olmayı, gerçek mutluluğun kaynağı olarak görmüştür. ${ }^{22}$ Ona göre gerçek mutluluk kişinin iyi ve kötü ayrımının yapılabilmesiyle alakalıdır. Buna göre iyi yani erdemli olan bilgi insanı mutluluğa götürecektir. ${ }^{23}$ Platon (MÖ 347)'a göre aklın erdemi bilgi, öfkenin erdemi yiğitlik ve şehvetin erdemi iffettir. Bu üç erdemin tertibinden ise adalet oluşmaktadır. Aklın erdemiyle adaletli olan insan ölümlü tarafından kurtularak, değişmeyen ölümsüz yanını güçlendirerek Tanrı'ya benzeyecek ve mutlu olacaktır. Mal, mülk, şöhrete veya hazlara sahip olmak ise geçicidir ve kişiyi mutlu etmeyecektir. ${ }^{24}$ Buna göre kişi aklını doğru bir şekilde kullandığında erdemli bir hayata sahip olacak ve bu da onu mutlu kılacaktır. ${ }^{25}$ Aristo felsefesine dayanan ve insanın ulaşmak istediği en yüce gayeyi mutluluk olarak ifade eden öğreti, eudaimonist ahlak öğretisi olarak tanımlanmaktadır. ${ }^{26}$ Aristoteles (MÖ 322)'e göre insanların nihai amacı mutlu olmaktır. Ancak insanların çoğu mutluluğun hazdan kaynaklandığını düşünmektedir. Mutluluk iyi, güzel ve

22 Bedia Akarsu, Ahlâk Ögrretileri 1 Mutluluk Ahlakı (İstanbul: İstanbul Üniversitesi Edebiyat Fakültesi Yayınları, 1965), 13-14,26-27.

23 Platon, Menon, Çeviren Furkan Akderin (İstanbul: Say Yayınları, 2013),87.

24 Hasan Hüseyin Bircan, İslam Felsefesinde Mutluluk (İstanbul: İz Yayıncılık, 2001), 25.

25 Platon, Phaidon, Çeviren Furkan Akderin (İstanbul: Say Yayınları,2015), 583.

26 Bircan, "İslam Ahlak Felsefesi”, 423. 
hoş olanı da beraberinde getirir. Ona göre, insanın kaderinde başına gelen güzel anlar veya büyük acılar mutlulukla ilişkili değildir. Mutluluk erdeme uygun olan eylemlerle alakalıdır. Bu nedenle sabretmesini bilen mutlu insanlar asla mutsuz olmazlar. ${ }^{27}$ Aristippos (MÖ 386) mutluluğu en yüksek hazza (hedone) erişmek olarak tanımlarken Epikuros (MÖ 270) hazda sürekliliği esas almıştır. Stoacılar hazzın insanı köleleştireceğini; bu nedenle gerçek mutluluğun kişinin kendisine egemen olmasını sağlayan erdemler olduğunu açıklamışlardır. ${ }^{28}$ Stoacı filozof Seneca (MS 65)'ya göre kötü görünen şeyler lehimize, iyi görünen şeyler ise aleyhimize olabilmektedir. Buna göre bazı şeylere sahip olduğu için mutlu olarak görülen insanlar aslında gerçek mutluluğa sahip değildirler. Boethius (524)'a göre ise Tanrı, gerçek mutluluk ve mükemmel iyi denilen şeyin bir ve aynısıdır. İnsan gerçek mutluluğa yönelmez ise güç, yeterlilik, şöhret vb. sahte mutluluklarla kendisini kandıracaktır. ${ }^{29}$

Ortaçağ Hristiyan dünyasında mutluluk öbür dünyada verilecek olan Tanrı'nın bir lütfu olarak görülmüştür. Aydınlanma çağında ise mutluluk her insanın bu dünyada erişebileceği bir hak olarak ifade edilmeye başlanmıştır. Bu şekilde insan, en yüce değer olan mutluluğa bu dünyada erişmenin yollarını aramalıdır. ${ }^{30}$ Aydınlanma dönemi düşünürlerinden olan Hume ${ }^{31}$ (1776) mutluluk ile mutsuzluğun iç içe geçtiğini belirtirken ${ }^{32}$ Kant (1804) herkesin kendi özel haz ve acı duygusuna göre mutluluğun kişiden kişiye değişebileceğinden bahsetmiştir. ${ }^{33}$ Kierkegaard (1855) umutsuzluğun kaynağını varlığın aşkın (Tanrısal) yanıyla olan ilişkisinin kesilmesi ve sadece sonlu varlığa odaklanmasında görmüştür. ${ }^{34}$ Schopenhauer (1860) ise insanın hayatında en çok mutlu olduğu anlarının, varlığının farkını en az idrak ettiği zamanlar olduğunu belirtmiştir. ${ }^{35}$

27 Aristoteles, Nikomakos'a Etik, Çeviren Furkan Akderin (İstanbul: Say Yayınları, 2014), 24, 29-36.

28 Bedia Akarsu, Ahlâk Öğretileri 1 Mutluluk Ahlakı (İstanbul: İstanbul Üniversitesi Edebiyat Fakültesi Yayınlar1, 1965), 13-14,26-27.

29 Emine Taşçi Yıldırım, İslam Felsefesinde İnâyet: İbn Sînâ Örneği (Ankara: Gece Kitaplı̆̆ı, 2020), 32,90.

30 Sebile Başok Diş, “Bir Dayatma Halini Alan Mutluluk Talebi”, Temaşa, 8, (2018): 39.

31 Sait Kar, "Din, Aydınlanma ve Eleştirisi," Atatürk Üniversitesi Illahiyat Fakültesi Dergisi, 42, (2014): 184.

32 David Hume, Din Üstüne, Çeviren Mete Tunçay (İstanbul: İmge yayınları, 1995): 96.

33 Nuran Tuzcuoğlu, “Kant’ta Ödev Ahlakının Temellendirilişi”” (Yüksek Lisans Tezi, İstanbul: Marmara Üniversitesi Sosyal Bilimler Enstitüsü, 2008), 114.

34 Soren Kierkegaard, Ölümcül Hastalık Umutsuzluk, Çeviren Mehmet Mukadder (Ankara: Doğu Batı Yayınları, 2004).

35 Arthur Schopenhauer, Hayatın Anlamı (İstanbul: Say Yayınları, 2008), 15. 
İslam filozoflarından Kindî (252/866)'ye göre insan mutlu olmanın yollarını aramalıdır. İnsanın üzüntü verecek şeylerden korunmaması kendisine bir zulümdür. Dünyadaki her şey değişmeye ve yok olmaya mahkûmdur. Bu nedenle kişi kendisine haz veren geçici nimetler peşinde koşmak yerine kalıcı olan ahlaki ve akli erdemlere yönelmelidir. ${ }^{36}$ Fârâbî (339/950) 'ye göre insanının nihai amacı mutluluktur. ${ }^{37}$ Mutluluk insanın maddeden arınıp ebedi mutluluğa erişmesidir. ${ }^{38}$

İbn Sînâ (428/1037)'ya göre insan özünde ruhanî lezzete sahiptir. İnsan bu lezzete hayvanî güçlerini aklın yönetimi altına sokarak ulaşabilir. Ancak buna ilahî destek görenler haricinde mutluluğa tam anlamıyla ahirette ulaşılacaktır. Çünkü insan nefsi ancak bedenden kurtulmakla mutlu olabilecektir. ${ }^{39}$

Gazâlî (555/1111) insanın içsel yönünde hayvanların, yırtıcıların, şeytanların ve meleklerin sıfatı olduğunu belirtmiştir. Kişi bu özelliklerden hangisine sahip olduğunu bilmedikçe mutluluğunu bilmeye gücü yetmez. Hayvanlar bedensel ihtiyaçlarını gidererek; yırtıcılar öldürerek, şeytanlar aldatarak; melekler ise Allah'ın cemalini seyrederek mutlu olurlar. Bu dünyada birkaç şeye sahip olarak veya yaşayarak geçici mutluluk sağlayabiliriz. Ancak asıl mutluluk insan gerçek hayata kavuştuğunda olacaktır. Orası seçilmiş kullar için Allah'ın cemali, avam için ise cennettir. O halde insan öncelikli olarak kendisini bilmelidir. Allah'ı tanımanın yolu insanın kendisini tanımasidır. ${ }^{40}$

Özetle kişinin mutluluğu hedonist felsefede fiziksel, entelektüel ya da sosyal tabanlı olup ihtiyaçlarının karşılanması ile ilgiliyken; eudaimonist felsefede kişinin kendisini gerçekleştirmesi ve anlamlı bir hayat sürdürmesi onu mutlu edecektir. ${ }^{41}$ Başka bir deyişle hedonist gelenekte mutluluğun pozitif etkisine odaklanılmakta ve olumsuz etkiler ötelenmektedir. Eudaimonist gelenekte odak tam ve derinden tatmin edici bir şekilde yaşam üzerinde durmaktadır. ${ }^{42}$ Eudaimonist felsefeye yakın

36 Mustafa Çağrıcı, “Kindi’nin Def’ul - Ahzan Adlı Risalesi, Kaynakları ve Tesirleri”, İstanbul: Marmara Üniversitesi Illahiyat Fakültesi Dergisi, (1995): 233.

37 Filiz Toprak Karakaya, Enver Uysal, "Fârâbî’de ‘İyi, Yetkinlik ve Mutluluk’ Kavramları Işı̆̆ıında PDR Hizmetlerine Farklı Bir Yaklaşım”, Sinop Üniversitesi Sosyal Bilimler Dergisi, 3/1, (2019): 201.

38 Bayram Tamtürk, “Farabi’nin Mutluluk Anlayışı” (Yüksek Lisans Tezi, Ankara: Gazi Üniversitesi Sosyal Bilimler Enstitüsü, 2006), 69-72.

39 Yıldırım, “İslam Felsefesinde İnâyet:”, 378-379.

40 Gazâlî, Kimyâ-yı Saâdet Mutlulukve Saadet Yolu, Çeviren Ali Arslan (İstanbul: Merve Yayınları, 2004): 14-15.

41 Alan S, Waterman, "Two Conceptions of Happiness: Contrasts of Personal Expressiveness (Eudaimonia) and Hedonic Enjoyment”. J. Pers. Soc. Psychol. 64, (1993): 679-680.

42 Edward Deci and Richard Ryan, "Hedonia, Eudaimonia and Well-Being: An Introduction," Journal of Happiness Studies, 9, (2008), 1. 
olan İslam filozoflarının görüşüne göre ise en yüksek iyi ve gaye olan mutluluğa nihai olarak insanlar öbür dünyada kavuşacaklardır. ${ }^{43}$

Aristoteles'in mutluluk düşüncesinden etkilenen İslam filozoflarına göre en yüce gaye ve en yüce iyilik olarak tanımlanan ve kişinin anlam arayışının ve bu dünyadaki amacının bir sonucu olan mutluluğa ancak erdemli olmakla erişilebilecektir. O halde mutluluk insanın doğru düşünce ve davranışlarıyla ilişkilidir. Ancak Attâs'ın belirttiği gibi felsefi yaklaşımda sadece akıl ön planda olmakla birlikte dinde vahiy ile vücut bulan tanrısal hikmet söz konusudur. Dini açıdan erdemler dışsal anlamda ibadetler, içsel anlamda iman gibi kalbin fillerine işaret etmektedir. İman sahibi insan ölüm ve ötesi ile ilgili korkularını yenecek, Allah'a isyan etmekten sakınıp salih amel işleyecektir. Hem dünyada hem de ahirette mutlu olmak için bu iki erdeme de sahip olmak gerekmektedir. ${ }^{44}$

\section{Psikolojide Mutluluk}

Psikologların görüşlerine bakıldığında çoğunlukla Aydınlanma felsefesinin etkisinde insanı merkez alan bir mutluluk anlayışı söz konusudur. Mutluluğa bakış açıları, teorileri üzerinden şekillenen psikologlara göre mutlu olmanın farklı yolları vardır.

Psikolojide iyi olan her şeyi temsil eden mutluluk kavramı, iyi oluş veya yaşam kalitesi gibi farklı kelimelerle ifade edilebilmektedir. ${ }^{45}$ Well being (iyi oluş) kişinin kendisini sağlıklı ve mutlu hissetmesi olarak tanımlanmaktadır. ${ }^{46}$ Öznel iyi oluşun içeriğinde pozitif etki, negatif etki ile birlikte hayat memnuniyeti de vardır. ${ }^{47}$ Yaşam memnuniyeti, bir kişinin yaşamının genel kalitesini bir bütün halinde olumlu olarak değerlendirme derecesidir. Başka bir deyişle, kişinin yaşadığı hayatı ne kadar sevdiğidir. ${ }^{48}$

43 Bircan, "İslam Ahlak Felsefesi," 422,425.

44 Nakîb Attâs, "İslam'da Mutluluğun Anlamı ve Tecrübesi," Çevien Şaban Ali Düzgün, Kelam Araştırmaları, 9/2, (2011): 225-227, 232.

45 Ruut Veenhoven, “Happiness: Also known as 'Life- Satisfaction' and 'Subjective Well-Being'”, In Handbook of Social Indicators and Quality of Life Research. Eds. Kenneth C. Land, Alex C. Michalos, and M. Joseph Sirgy. Dordrecht, Netherlands: Springer Publishers, (2012): 1-2.

46 Cambridge Dictionary, "Well Being”, 13 Nisan 2020, https://dictionary.cambridge.org/tr/ s\%C3\%B6zl\%C3\%BCk/ingilizce/well-being.

47 Ed Diener, Emmons, Robert A., Larsen, Randy J., and and Griffin, Sharon, "The Satisfaction With Life Scale", Journal of Personality Assessment, 49/1, (1985): 71.

48 Ruut Veenhoven. “The Study Of Life Satisfaction”, In W. E. Saris, R. Veenhoven, A. C. Scherpenzeel, and B. Bunting (Eds.), A Comparative Study Of Satisfaction With Life In Europe. Budapest: EOtvOs University Press, 1996, 11-48. 
Psikolojide de genelde mutluluğu zevk veya acıdan kaçınma olarak tanımlayan hedonik yaklaşım; anlam ve kendini gerçekleştirmeye odaklanan eudaimonik yaklaşım olmak üzere iki perspektiften çalışmalar yapılmıştır. ${ }^{49}$ Psikolojide tarihsel süreç içerisinde mutluluk ile ilgili yorumlara bakacak olursak Freud, yaşamın amacı olarak ele aldığı mutluluğu haz ilkesiyle açıklamıştır. Ona göre mutlu olmak için acıdan kaçınmak ve haz duyguları yaşamak gerekmektedir. ${ }^{50}$ Mutluluk aslında bu dünya için bir hayalden ibaret olsa da insan özellikle ihtiyaçlarının tatmin edildiği bazı anlarda mutlu olabilir. ${ }^{51}$ Horney, kişinin mutlu olması için öncelikli olarak kıskançlık gibi yıkıcı/nevrotik düşüncelerden kendisini arındırması gerektiğinden bahsetmiş̧tir. ${ }^{52}$ Jung'a göre mantıklı olduğuna ikna olduğunda insanın en büyük zorluklara dayanabilme gücü vardır. Ayrıca insan ancak bilinçli ve bilinçsiz barış içinde yaşamayı ve birbirini tamamlamayı öğrendiğinde ve bireyleşme süreci tamamlandığında bütünleşmiş, sakin, verimli ve mutlu olacaktır. ${ }^{53}$

Maslow ise kişinin kendisini gerçekleştirmesi sonucu kaygı ve sorunlarıyla başa çıkma, yaşamdan tat alma, mutlu ve huzurlu olma gibi duyguları tadacağından bahsetmiştir. ${ }^{54}$ Fromm'a göre kişinin mutlu olması için yaşamayı ve sevmeyi bilmesi gerekmektedir. ${ }^{55}$ Borgna' ya göre insanlar kendilerini mutlu edecek şeylerin peşinden koşmaktadır. Ancak bu mutluluk kaynağı olarak algıladıkları şeyler, çok çabuk uçup gidebilen dünyevi isteklerdir. Kalıcı mutluluk ise içsel deneyimlerle ilişkilidir. İçsel veya yaratıcı yalnızlık, kişiyi her tür dünyevi acı ve ıstıraptan uzaklaştırır. $^{56}$

Psikolojide ilk dönemlerde depresyon ve kaygı gibi olumsuz duygular üzerinde durulmuş, ancak pozitif psikolojinin de ortaya çıkmasıyla zamanla olumlu duygular

49 Richard Ryan and Edward Deci, "On Happiness and Human Potentials: A Review Of Researchon Hedonic and Eudaimonic Well-Being”, Annu. Rev. Psychology, 52, (2001): 141.

50 Freud, "Uygarlık, Toplum ve Din”, 34, 39.

51 Sigmund Freud, Mutluluk Dediğimiz Şey Aforizmalar Çeviren Peren Demirel (İstanbul: Aylak Adam Yayınları, 2017),27,41.

52 Karen Horney, Çăğmızın Tedirgin İnsanı, Çeviren Ayda Yörükan (İstanbul: Tur Yayınları, 1980), $180,261$.

53 Carl Gustav Jung, Man and His Symbols, Concieved and Edited By Carl Gustav Jung (New York: Anchor Press Book, 1964) 14, 76.

54 Abraham Maslow, İnsan Olmanın Psikolojisi, Çeviren Okhan Gündüz (İstanbul: Kuraldışı Yayınevi, 2001), 167.

55 Erich Fromm, Sahip Olmak ya da Olmak, Çeviren Aydın Arıtan (İstanbul: Arıtan Yayınları, 1994), 87-88.

56 Eugenio Borgna, Ruhun Yalnızlı̆̆g, Çeviren Meryem Mine Çilingiroğlu (İstanbul: Yapı Kredi Yay, 2014), 80, 88. 
ön plana çıkartılmaya başlanmıştır. ${ }^{57}$ Özellikle 1960 'l1 y1llardan sonra psikoloji kuramları çevreden çok benliğe odaklanmıştır. Kişiye birçok şeyin kendi elinde olduğu bir özgürlük ortaya koymuştur. Bireyin zevkleri, acıları, benliği ve kişisel doyumu kutsal bir hakka dönüşmüştür. ${ }^{58}$ Günümüzde ise mutluluk popüler araştırma konuları arasında yer almaktadır. ${ }^{59}$ Pozitif psikoloji öncülerinden olan Seligman'a göre mutluluk gibi duygulara insanlar kişisel güçlere ve erdemlere sahip olarak ulaşılabilecektir. ${ }^{60}$ Csikszentmihalyi ise mutluluğun kaynaklarından (elde etme yollarından) birinin akış deneyimini yaşayabilmek olduğunu belirtmiştir. ${ }^{61}$

Mutluluk için hazlardan içsel deneyimlere kadar yöntemler sunulmakla birlikte mutluluğun aranılacak veya elde edilecek bir his olmadığından da bahsedilmektedir. İnsanlar bu duyguyu fazlasıyla önemsedikleri için aslında daha fazla mutsuz olmaktadırlar. Frankl, mutluluğa farklı yaklaşmış; onun elde edilmesi gibi bir zorunluluk olmadığından bahsetmiştir. Ona göre mutluluk aranılmaz, anlam arayan insanın içsel yolcuğunda yaşayabileceği bir duygudur. Mutlu olmanın zorunlu tutulması Amerikan kültüründen gelmektedir. ${ }^{62}$ Marar'a göre ise mutluluk insanlar için bir paradoks haline gelmiştir. Çünkü insan bir taraftan kendi istediği gibi özgürce yaşamayı arzulamakta diğer taraftan başkalarını memnun etmek istemektedir. $\mathrm{Bu}$ nedenle mutluluk arayışı bir hedef olmaktan çok hayalcilik ile sorumluluk arasında kalmıştır. $^{63}$

Modern zamanda mutluluğun insanların elde etmesi gereken bir hak olarak algılanması, insanların mutlu olmak için çaba sarf etmesine, bu dünyada mutlu olmak için elinden gelen her şeyi yapmasına ve mutsuzluğunun artmasına neden olmuştur. Çünkü mutluluk kişinin her zaman yaşayacağı bir durum değildir. Mutluluğu insanın elde edebileceği bir olgu olarak yansıtmak onu Tanrı' dan beklemekten daha yıpratıcıdır. Artık kişi eğer mutsuzsa bunun nedeni talihi ve Tanrı değil;

57 İlker Kaba, Murat Erol ve Kadir Güç, "Yetişkin Yaşam Doyumu Ölçeğinin Geliştirilmesi”, Anadolu Üniversitesi Sosyal Bilimler Dergisi, (2017): 2.

58 Martin E.P. Seligman, Öğrenilmiş İyimserlik, Çeviren Semra Kunt Akbaş (Ankara: Boylam Psikiyatri Enstitüsü Yayınları, 2007),11.

59 Halil İbrahim Özasma, "Pozitif Psikoloji ve İslam Düşünürlerinde Erdemler” (Yüksek Lisans Tezi, Ankara Üniversitesi, 2016), 126.

60 Martin Seligman, Gerçek Mutluluk, Çeviren Semra Kunt Akbaş (Ankara: HYB Yayınları, 2002), 30.

61 Mihaly Csikszentmihalyi, Akış- Mutluluk Bilimi, Çeviren.Barış Satılmış (İstanbul: Buzdağ1 Yayınc1lık, 2017), 74-142.

62 Victor Frank1, İnsanın Anlam Arayışı (İstanbul: Öteki yayınları, 2000), 127.

63 Ziyad Marar, Mutluluk Paradoksu Özgürlük ve Onaylanma, Çeviren Serpil Çağlayan (İstanbul: Kitap Yayınevi, 2004), 13, 181. 
kendisi, kendi başarısızlığıdır. Teknoloji, bazı acı ve zorlukları ortadan kaldırsa da yeryüzünde acılar devam etmektedir. Bu nedenle insanın daima mutlu olması gibi durumu olmadığı gibi mutsuzluk da mutluluk kadar doğal bir duygudur. Ayrıca Tanrı'nın insanı mutlu etmek gibi bir görevi de yoktur. ${ }^{64}$

Buna göre mutlulukla ilgili hazcı açıklamalarla birlikte mutlu olmak için kişinin kendisini tanımasının önemsenmesi, çevreden ve sahip olunan şeylerden çok içsel yaşantılara önem verilmesi ön plana çıkmaya başlamıştır. Ayrıca mutluluğun insanın nihai amacı olmaması ve hüzün gibi geçici bir his olarak algılanması gerektiğine dair görüşler, ütopik mutluluk anlayışından uzaklaşıldığını göstermektedir.

\section{Din, Dindarlık ve Mutluluk}

Dinler hayatın psikososyal, ekonomik, siyasi, biyolojik ve fiziki yönüyle iç içe geçmiştir. ${ }^{65} \mathrm{Bu}$ nedenle inanan bireyi duyuş, düşünüş ve davranış açısından dönüştürmektedir. Ayrıca kişinin hayatına bir anlam ve amaç ile belirli bir kimlik duygusu kazandırmaktadır. ${ }^{66}$ Buna göre insanın düşüncelerini, tutumlarını ve davranışlarını etkileme gücü olan din, kişinin hayata bakış açısını dönüştürebildiği gibi mutluluk ile ilgili tutum ve davranışını etkileyebileceğinden söz edebiliriz.

İslam dini insanın benliğindeki zayıf yönlerine işaret eder; sosyal ilişkilerden affedici, adil, alçakgönüllü olmak gibi emirlerde bulunup kişiyi ruhsal açıdan mutlu olmaya yönlendirir. ${ }^{67}$ Diğer dinlerde olduğu gibi insanlara bir yaşam planı sunar. Bu plan dâhilinde yaşayan insanların hem bu dünyada hem de öbür dünyada mutlu olacağı vaat edilir. ${ }^{68}$ İslam dininin mutluluk anlayışı ile ilgili öncelikli olarak ayetlere baktığımızda Kur'an-1 Kerim'de Allah'a itaat edenlerin, O'nun rızasını gözetenlerin mutlu olabileceğinden bahsedilmiştir. Korkunun, üzüntünün ve acıların olmayacağ 1 yer ahiret hayatıdır. Buna göre mutluluk ahirette gerçekleşeceği için ulaşılması gereken mutluluk öteki hayatta olacaktır. Kur'an-1 Kerim'de emredilenleri yapanlar hem bu dünyada hem de ahirette mutlu olacaklardır. Tam ve gerçek mutluluk uhrevi mutluluk olduğu için insanlar bu mutluluğu dini ve ahlaki açıdan iyi davranışlarıyla elde edeceklerdir. Ancak bu iyi davranışların amacı Allah'ın rızasını kazanmak olmalıdır. ${ }^{69}$ Kur'an'da mutluluk kavramı dünya ve ahiret olmak üzere iki yönlü bir

64 Sebile Başok Diş, "Bir Dayatma Halini Alan Mutluluk Talebi”, Temaşa, 8, (2018), 27-41.

65 Neda Armaner, Din Psikolojisine Giriş (Ankara: Ayyıldız Matbaası, 1980), 71.

66 Asım Yapıcı, Ruh Sağlığı ve Din (Adana: Karahan yayınları. 2007), 19.

67 T.A. Baasher, "İslam and Mental Health", Eastern Mediterranean Health Journal, 7/3, (2001): 374.

68 Taner Cücü, İslam 'da Mutluluk Prensibi (İstanbul: Otağ Yayınları, 1978), 249.

69 Bircan, "İslam Felsefesinde Mutluluk", 38-48. 
anlama sahiptir. Kur'an'ın emirlerine göre fitrata uygun yaşandığında kişinin ruhsal sağlığı korunacaktır. Kur'an'da mutluluğun şartı öncelikli olarak iman etmek ve sonrasında salih ameller işlemektir. Kur'an ölçüsünde yaşayan kişi problemlerinin fazla üzerinde durmayarak duygularının kontrolünü sağlayacak ve sabır, merhamet, güven gibi olumlu duyguları kendisine katmasını sağlayacaktır. ${ }^{70}$

Hadislerde ise iman ve ibadet etmenin kişiyi mutlu edeceği vurgulanmaktadır. Ayrıca ahlaklı olmak, doğru davranışlar sergilemek insanları mutlu edecektir. Bu olgular dünya ve ahiret mutluluğunu amaçlamaktadır. ${ }^{71}$

Mutluluk kavramı, İslam ahlakçıları tarafından da ele alınan kavramlar arasında yer almaktadır. ${ }^{72}$ İslam ahlakçılarına göre kişinin mutluluğa ulaşmasının şartı bilgi ve hikmet sahibi olmakla birlikte mutluluğa ulaşmak ancak erdemli davranışlarla mümkündür. ${ }^{73}$ Yahya Bin Adi'ye göre (öl. 364/975) insan iffetli, faziletli, adil ve yardımsever olduğunda mutlu olabilecektir. ${ }^{74}$ İbn Miskeveyh'e göre ise (öl. 421/1030) insanın yeme, içme, cinsellik gibi bedenle alakalı beklentileri karşılanabilir ancak bu gerçek mutluluk değildir. Kişi en yüce mutluluğa düşünme ve ayırt etme yeteneğiyle ulaşacaktır. Böylece mutluluğu dışarıdan değil içeriden gelen kişi, başına gelenlere göre mutlu veya mutsuz olmaz. Kendisiyle mutlu olan kişi gerçek varoluşun farkındadır ve iyi ahlaklı oldukça kişide mutluluk ortaya çıkacaktır. ${ }^{75}$ Kınalızade'ye göre (öl. 979/1572) ise geçici arzularının peşinde koşanlar dünya ve ahiret mutluluğunu yitirecektir. ${ }^{76} \mathrm{Bu}$ nedenle mutluluk, kişinin ahlaklı olmasına bağlıdır. Ayrıca kişinin mutlu olması için güzel işler yapması ve itikat sahibi olması gerekmektedir. ${ }^{77}$ Bu yorumlara göre kişinin mutlu olması iradesini doğru bir biçimde kullanması, ahlaklı olması ve iyi işler yapmasıyla alakalıdır.

70 Havva Yalvaç Arıc1, “Kur'an'da Mutluluk Kavramı ve Eğitimi," Doktora Tezi. (İstanbul: İstanbul Üniversitesi Sosyal Bilimler Enstitüsü.2019), 272-273.

71 Sümeyye Bilgen,” Hadislerde Mutluluk ve Mutsuzluk Sebepleri”, Yüksek Lisans Tezi,( Isparta: Süleyman Demirel Üniversitesi Sosyal Bilimler Enstitüsü,2018), 15-16.

72 Hasan Ocak, "Kınalızâde Ali Efendi'de Mutluluk Ahlakı Kavramının Felsefi Temelleri”, I ğdır Üniversitesi Sosyal Bilimler Dergisi 1, (2012): 115.

73 Murat Demirkol,’’Islam Ahlak Düşüncesinin Gelişiminde Filozofların Katkısı”,Eskiyeni 28, (2014): 83-84.

74 Yahya Bin Adî,Tahzibü'l-Ahlâk, Çeviren Harun Kuşlu,(İstanbul: Türkiye Yazma Eserler Kurumu Başkanlığı, 2013), 54.

75 İbn Miskeveyh, Mutluluk ve Felsefe Mutluluk Mertebelerinin Düzenlenmesi (ve İlimlerin Menzilleri), Neşir, Tercüme ve İnceleme:Hümeyra Özturan (İstanbul: Klasik Yayınları, 2017),5365

76 Kınalızade Ali Efendi, Ahlâk-ı Alâ̂i, Hazırlayan Hüseyin Algül, İstanbul: Tercüman 1001 Temel Eser, t.y.), 162.

77 Ocak, "Kınalızâde Ali Efendi'de Mutluluk", 134. 
Mistik öğretilerin de insanlara mutluluk ile ilgili yol gösterdiklerinden bahsedilmektedir. ${ }^{78}$ İnsanın fitratında var olan aşk, sevgi, yakınlık ve şefkat gibi duygular bireye mutluluk getirecektir. ${ }^{79}$ Mutsuzluk, bir durumdan çok insanların düşünceleriyle alakalıdır. Bu nedenle bireyin zihnindeki kurguladıkları yerine gerçek ile kalmaya çalışması gerekmektedir. ${ }^{80}$ Mutlak mutluluk, bireyin kendi varlı̆̆ını/ kendiliğini bilmesidir. Varlığının kendisinden başka hiçbir şeye ihtiyacı yoktur. ${ }^{81}$

İslam mistisizmi diyebileceğimiz tasavvufta ${ }^{82}$ ideal insan profili tanımlandığı görülmektedir. Tasavvuf insanın mal, mülk, şöhret veya makamın kontrolüne girmemesini; nefsin arzularına karşı kontrollü olabilmesini; öfke, nefret gibi duygularını kontrol etmesini; sabırlı olmasını; şükredebilmesini; gerçekleşmesi muhtemel olumsuzluklardan korkmamasını; her daim Allah'ın rahmetinden ümidini kesmemesini amaçlar. ${ }^{83}$ Tasavvuf, varoluşuna yabancılaşan modern insanı kendisine yönelterek ${ }^{84}$ bireyi içsel yolculuğa yönlendirir ve bu şekilde bireyin varlığını anlamlandırmasını hedefler. ${ }^{85}$ Buna göre tasavvufta kişinin kendisini tanıması ve uygularını kontrol etmesi amaçlanmaktadır. Kendisini tanıyan insan, mutluluğu başka yerde aramayacaktır.

Din insanı kişiler arası ilişkilerde daha yapıcı, yardımsever, hoşgörülü, cömert olmaya teşvik eder. İnsanın sosyal ortamda etkileşimi yardım etmesini veya yardım almasını sağladığı için kendi problemlerini çözmesini kolaylaştırabilecektir. ${ }^{86}$ Buna göre dini öğretiler insanların hem bu dünyada hem de öbür dünyada mutlu olmasını amaçlamaktadır. Bu mutluluk anlayışı, mahiyet olarak insanların sahip olmaya çalıştığ 1 şöhret, servet gibi maddi şeylere dayanmamaktadır. Hatta maddeye dayalı bir mutluluk algısının geçiciliğinden bahsedilmektedir.

78 Albrecht Classen, "Mystical Visions and Spiritual Health -Medieval Mysticism as a Platform For The Exploraton of Human Spirituality and Happiness," Studies in Spirituality, 25, (2015): 138 ;

79 Dalai Lama,and Howard C. Cutler, M.D., Mutluluk Sanatı (İstanbul: Dharma Yayınları, 2000), 63, 66.

80 Echart Tolle, A New Earth Awakening is Your Lifes Purpose (Usa: Penguin Group, 2008), 59.

81 Rupert Spira, Happiness Is Knowing Our Own Being, https://non-duality.rupertspira.com/read/ happiness_is_knowing_our_own_being Erişim 4.04.2020.

82 Erol Güngör, İslam Tasavvufunun Meseleleri (İstanbul: Ötüken Yayınları), 17.

83 Hasan Kayıklık, Tasavvuf Psikolojisi (Ankara: Akçağ yayınları, 2009), 231.

84 Lynn Wilcox, Sufism and Psychology, (Chicago: Abjad Book Designers \& Builders,1995), 3,206 .

85 Ömer Faruk Altıparmak, "İslam Düşüncesi Bağlamında Tasavvufun Yeri Üzerine Bir Derkenar," Harran Üniversitesi Illahiyat Fakültesi Dergisi, 20/33, (2015): 34.

86 Harold G. Koenig and David B. Larson, "Religion and Mental Health : Evidence for An Association", International Review of Psychiatry 13/2, (2001): 72. 
Tecrübi araştırma bulgularından eudaimonik yaklaşımı destekleyici bulgular bulunmaktadır. Mutluluk, hayat memnuniyeti ve iyi oluş ile ilgili araştırma sonuçlarına göre hayat memnuniyeti veya psikolojik iyi oluşun, şükürve affetme gibi prososyal davranışlarda anlamlı bir etkisinin olduğu görülmüş̧ür. ${ }^{87}$ Araştırmalardan bazılarını inceleyecek olursak 2020 Dünya mutluluk araştırmasına göre 156 ülke arasında Türkiye 93. Sırada yer almıştır. Finlandiya, Danimarka, İzlanda, Norveç gibi Kuzey ülkeleri ise ilk sıralarda yer almıştır. Özellikle bu ülkelerin ekonomik açıdan halka refah bir hayat sağlaması, vaat ettiklerini gerçekleştirmeleri, çeşitli problemlerde halkının yanında olmaları, kurumlarının yozlaşmamış ve kaliteli olmasına bağlamışlardır. ${ }^{88}$ TÜIK 2019 yılı verilerine göre Türkiye'de mutlu olduğunu belirten insanların oranı \%52,4'tür. Mutluluklarının kaynağı ise \%74,1 aile ve \%69,9 ile sağlıklı olmaktır. ${ }^{89}$ Kangal, 2004- 2010 yılları arası ülkemizde öznel iyi olma çalışmalarında kadınların, eğitim düzeyi yüksek olanların, evlilerin daha mutlu olduklarını tespit etmiştir. ${ }^{90}$

Park ve arkadaşlarının 27 ülkeden toplam 28836 yetişkin ile yapılan çalışmada anlam ve bağl1lı̆̆ın yaşam memnuniyetiyle ilişkili olduğu bulunmuştur. ${ }^{91}$ Peterson'un araştırma sonucunda zevk, bağl11ık ve anlam yöneliminin her birinin ayrı ayrı

87 Ali Ayten ve Hamza Ferhan, "Forgiveness, Religiousness, and Life Satisfaction: An Empirical Study on Turkish and Jordanian University Students," Spiritual Psychology and Counseling, 1/1, (2016): 75-84; Ali Ayten ve Fehim Gashi, "Affetme ve Hayat Memnuniyeti Üzerine Karşılaştırmalı Bir Araştırma." Balkan Araştırmaları Dergisi, 3/2 (2012): 11-36; Ali Ayten ve Hatice Tura, “Affetme ve Dindarlık, Hayat Memnuniyetini Nas1l Destekler?” İslâmî İlimler Dergisi, 12, 12/3, (2017); Ali Ayten and Sezai Korkmaz, "The Relationships Between Religiosity, Prosociality, Satisfaction With Life And Generalised Anxiety: A Study On Turkish Muslims," Mental Health Religion and Culture, (2020): 980; Bono, Giacomo, McCullough, Michael E. and Root, Lindsey M., "Forgiveness, Feeling Connected to Others, and Well-Being: Two Longitudinal Studies," Personality and Social Psychology Bulletin, 34, (2008): 182; Khirizad, Babak, "Transpersonel Psikolojide Affetmek," (Doktora Tezi. Ankara: Ankara Üniversitesi. Sosyal Bilimler Enstitüsü, 2017).

88 Frank Martela, Bent Greve, Bo Rothstein, and Juho Saari. "The Nordic Exceptionalism: What Explains Why the Nordic Countries are Constantly Among the Happiest in the World". in 2020 World Happiness Report, Edit: Editors: John F. Helliwell and others, (A publication of the Sustainable Development Solutions Network, 2020): 140. Erişim tarihi 23.03.2020. https:// happiness-report.s3.amazonaws.com/2020/WHR20.pdf.

89 TÜİK, "Yaşam Memnuniyeti Araştırması 2019," Erişim: 23.02.2020. file://C:/Users/hasan/ AppData/Local/Temp/Temp1_Yaşam_Memnuniyeti_Araştırmas1_17.02.2020\%20(1).zip/ Haber_Bulteni.pdf

90 Ayça Kangal, "Mutluluk Üzerine Kavramsal Bir Değerlendirme ve Türk Hane Halkı İçin Bazı Sonuçlar,” Elektronik Sosyal Bilimler Dergisi, 12. 44, (2013): 229.

91 Nansook Park, Christopher, Peterson, Willibald, Ruch, "Orientations to Happiness and Life Satisfaction in Twenty-Seven Nations," The Journal of Positive Psychology, 4,4, (2009): 273. 
yaşam memnuniyetini arttırdığ 1 bulgulanmıştır. ${ }^{92}$ Ryff psikolojik iyi olma halinin tanımlanmasında "başkalarına yönelik bir yönelimin" (Şefkatli olma, iyi ilişkiler kurma) yanı sıra, mizah duygusu, hayattan zevk alma ve değişimi kabul etme başarılı yaşlanma gibi kriterlerin etkili olduğu görülmüsşür. ${ }^{93}$ Diener ve Diener'in 31 ülkede 13,118 üniversite öğrencisi ile yapmış oldukları araştırma sonucunda finansal, arkadaş ve aile memnuniyetlerinin yaşam memnuniyeti ve benlik saygisı ilişkisi ile ilgili ülkeler arasında farklılık göstermiş̧ir. Finansal memnuniyet, yoksul ülkelerde yaşam doyumu ile daha güçlü bir korelasyonda çıkmıştır. ${ }^{94}$ Emmons, sosyal ve kişisel kaynakların öznel iyi oluş ile genel olarak maddi kaynaklardan daha güçlü bir şekilde ilişkili olmasıyla nitelendirilmiştir. ${ }^{95}$ Kaya ve Orçan'ın araştırma sonucunda mutluluğun empati, yaşam doyumu ve affetme arasında aracı rolü olduğu saptanmıştır. ${ }^{96}$

Araştırma sonuçlarına bakıldığında psikologlar insanı merkeze alan bir yaklaşımla mutluluğu elde etmek için felsefedeki haz ve erdem ekseninde değerlendirmelerde bulunmuşlardır. İlk yaklaşımlarda insanın arzularının farkında olmasından bahsedilmiş, sonrasında ise kendisini gerçekleştirmesi; affetmeyi, sevmeyi bilmesi, bir anlam ve amaç edinmesi üzerinde durulmuştur. Özellikle amprik araştırmalar bize eudaimonik düşüncenin insanlar açısından daha önemli olduğunu göstermiştir.

İnsanlar sağlık sorunları gibi yaşadıkları olumsuz olayları başkalarından destek aldıkları zaman daha kolay atlatabilmektedirler. Özellikle dini gruplar insanlara yaşadıkları sıkıntılı anlarda veya yalnız kaldıklarında destek sağlamaktadır. ${ }^{97}$ Araştırma sonuçlarına bakıldığında dindar insanların dini hizmetlere katılması, cemaat içi sosyal ilişkilerinin olması, kilise üyeliği, kilise etkinliği, dini kitap okuma, dini TV/radyo dinleme, dua etme ${ }^{98}$ gibi faaliyetlerin bu konuda etkili olduğu

92 Peterson, Christopher, Park, Nansook, Seligman, Martin E.P. “Orientations to Happiness and Lise Satisfaction: The Full Life Versus The Empty Life”, Journal of Happiness Studies, 6, (2005): 25.

93 Carol D Ryff, "In the Eye of the Beholder: Views of Psychological Well-Being Among MiddleAged and Older Adults". Psychol. Aging 4, (1989): 195.

94 Ed Diener and Marissa Diener, "Cross-Cultural Correlates of Life Satisfaction and Self- Esteem", J. Pers. Soc. Psychol. 68, (1995): 653.

95 Robert A Emmons, "Personal Strivings: an Approach to Personality and Subjective Wellbeing", J. Pers. Soc. Psychol. 51, (1986): 1058.

96 Özgür Salih Kaya ve Fatih Orçan, "Mutluluğun Empati, Affetme ve Yaşam Doyumu Arasındaki Aracı Rolü: Bir Yol Analizi,” Bolu Abant İzzet Baysal Üniversitesi Eğitim Fakültesi Dergisi, 19/2 (2019): 540-554.

97 Michael E. Nielsen, "Din ve Mutluluk”, Bilimname XXXIII, 1, (2017): 141-144.

98 Levin Jeffrey S. and Robert Joseph Taylor, "Panel Analyses of Religious Involvement and Well-Being in African Americans: Contemporaneous vs. Longitudinal Effects," Journal for the Scientific Study of Religion, 37/4, (1998): 695. 
görülmüştür. Pew araştırma merkezinin 2019 yılı araştırma sonucuna göre ABD'de ve dindarların daha mutlu oldukları; $A B D$ ve 25 ülkede yapılan analize göre bu kategorilerden istatistiksel açıdan dini etkinliklere katılan "aktif dindarlar"'n daha mutlu oldukları ortaya çıkmıştır. ${ }^{99}$ Sonuç olarak kişinin hayatında bir anlamı ve amacı olması, bağlılı̆ı̆n, aile ve arkadaş ortamları gibi sosyal ilişkilerin, maddiyatın, şükran, affetme duygularının iyi ve mutlu olmasını, yaşam memnuniyetini sağlayabilir.

Yüce bir varlığa inanç insanların anlamlı bir hayat yaşamalarını sağlamaktadır. ${ }^{100}$ Dindarlık olumsuz deneyimler, korkularla başa çıkma, amaç duygusu ve aidiyet ihtiyacını karşılama nedenleriyle bireylerin mutluluğu üzerinde olumlu bir etkisi olabilmektedir. ${ }^{101}$ Araştırma sonuçları ağırlıklı olarak mutluluk, hayat memnuniyeti ve iyi oluş ile dindarlık veya dini yönelim arasında pozitif yönde bir ilişki olduğu; dindarlık veya dini yönelim arttıkça mutluluk, öznel iyi oluş ve hayat memnuniyetinin arttığ1 görülmüştür. ${ }^{102}$

99 Pew Research Center, "Religion's Relationship to Happiness," Civic Engagement and Health Around the World, 2019.

https://www.pewforum.org/2019/01/31/religions-relationship-to-happiness-civic-engagementand-health-around-the-world/ Erişim : 9.1.2020.

100 Seligman, "Gerçek Mutluluk", 39.

101 Özlem Yorulmaz, "Relationship Between Religiosity and Happiness in Turkey: Are Religious People Happier?" Çankırı Karatekin Üniversitesi İktisadi ve İdari Bilimler Fakültesi Dergisi, 6/1, (2016), 813.

102 Gülüşan Göcen, "Pozitif Psikoloji Düzleminde Psikolojik İyi Olma ve Dini Yönelim İlişkisi: Yetişkinler Üzerine Bir Araştırma,” Toplum Bilimleri, 7/13, (2013), 122; Durmuş Sevindik, “Orta Yaş Dönemi Bireylerde Dindarlık Mutluluk İlişkisi: (Denizli Örneği)" (Yüksek Lisans Tezi. Isparta: Süleyman Demirel Üniversitesi Sosyal Bilimler Üniversitesi, 2015), 103; Nevzat Gencer, "Hemodiyaliz Hastalarında Dindarlık ve Öznel İyi Oluş," (Doktora Tezi, Çorum: Hitit Üniversitesi Sosyal Bilimler Enstitüsü, 2019), 259; Nurten Taş, “Tıp ve İlahiyat Fakültesi Öğrencilerinde Batıl İnanç, Dindarlık ve Mutluluk İlişsisi”, (Yüksek Lisans Tezi Çanakkale: Çanakkale Onsekiz Mart Üniversitesi Sosyal Bilimler Enstitüsü, 2019), 113; Rüveyda Efdal Aydemir, "Dindarlık ve Mutluluk İlişkisi (İlk Yetişkinlik Dönemi)", (Yüksek Lisans Tezi, Çanakkale: Çanakkale Onsekiz Mart Üniversitesi Sosyal Bilimler Enstitüsü, 2008), 65; Asiye Acaboğa, "Din Mutluluk İlişkisi” (Yüksek Lisans Tezi. Kahramanmaraş: Sütçü İmam Üniversitesi Sosyal Bilimler Enstitüsü, 2007), 57; Ali Keleş, "Din Görevlilerinde Dindarlık ve Mutluluk Arasındaki İlişki (Sivas Örneği)”, (Yüksek Lisans Tezi, Sivas: Sivas Cumhuriyet Üniversitesi, 2019), 132; Özlem Yorulmaz, "Relationship Between Religiosity and Happiness in Turkey: Are Religious People Happier?" Çankırı Karatekin Üniversitesi İktisadi ve İdari Bilimler Fakültesi Dergisi, 6/1, (2016), 801; Alper Sönmez, ve Özlem Altınsu Sönmez, "Life Satisfaction and Happiness with Regard to Human Capital and Religiosity in Turkey," Bingöl Üniversitesi Sosyal Bilimler Enstitüsü Dergisi, 8/16, (2018), 217; Benjamin Beit Hallahmi, and Michael Argyle, "Dindarlığın Etkileri 1," Çeviren Adem Şahin, Selçuk Üniversitesi Illahiyat Fakültesi Dergisi, 10, (2000): 453; Yahya Turan, "Yalnızlıkla Başa Çıkma: Yalnızlık, Dini Başa Çıkma, Dindarlık, Hayat Memnuniyeti ve Sosyal Medya Kullanımı". Cumhuriyet İlahiyat Dergisi 22 (2018): 395-434. 
Krause, çalışmasında yaşlı yetişkinlerde dindarlık ile yaşam doyumu, benlik saygısı ve iyimserlik arasında anlamlı bir ilişki çıkmıştır. ${ }^{103} \mathrm{Abdel}-\mathrm{Khalek}$ Lübnanlı genç yetişkinler arasında mutluluk, sağlık ve dindarlık araştırmasında kendilerini mutlu hissedenler, daha yüksek zihinsel ve fiziksel sağlik bildirdikleri ve daha dindar oldukları sonucuna varılmıştır. ${ }^{104}$ Koenig, dindarlık ile sağlık arasında meta analiz çalışması yapmış ve ikisi arasında anlamlı bir ilişki çıkmışıtır. ${ }^{105}$ Ahrenfeldt ve arkadaşlarının yapmış olduğu çalışmaya göre dua etme, belirli bir dini organizasyonda yer alma veya dini eğitim almış olmak iyi sağlıkla ilişkili çıkmıştır. ${ }^{106}$ Lim ve Putnam'ın araştırma sonucuna göre dindarlık hayat memnuniyetine olumlu yönde etki etmektedir. Bunun en önemli nedeni ise dindar insanların düzenli olarak dini hizmetlere katıldıkları ve cemaatlerinde sosyal ağlar kurdukları için yaşamlarından daha memnun olduklarını göstermektedir. Bununla birlikte, cemaat içi dostluğun etkisi, güçlü bir dini kimliğin varlığına bağlıdır. ${ }^{107}$ Sillick ve arkadaşlarının çalışmasında ise dindarlık ve mutluluk arasında pozitif bir ilişki bulunan araştırmaların aksine 124 kişi ile yapılan çalışmada dindar olanlar, dindar olmayanlara göre daha mutlu çıkmamıştır. ${ }^{108}$ Francis' in yapmış olduğu araştırma sonucunda kişilikteki bireysel farkl1lıkları göz önüne alarak dindarlık ve mutluluk arasında küçük ama istatistiksel olarak anlamlı bir ilişki olduğunu bildirmiştir. ${ }^{109}$ Ayten ve arkadaşlarının çalışmasında 114 hasta, hasta yakını ve hastane çalışanlarıyla yapmış olduğu araştırmada hayat memnuniyeti ile şükür ve olumlu dini başa çıkma arasında olumlu ve anlamlı ilişki tespit edilmiştir. ${ }^{110}$ Yine Ayten"'in araştırmasında dindarlığın hem affetme eğiliminde hem de hayat

103 Neal Krause, "Religious Meaning and Subjective Well-Being in Late Life", The Journals of Gerontology,58/3, (2003): 160.

104 Ahmed M. Abdel-Khalek, "Happiness, Health, and Religiosity: Significant Associations Among Lebanese Adolescents," Mental Health Religion \& Culture, 17/1, (2014): 1

105 Harold G. Koenig, "Religion, Spirituality, and Health: The Research and Clinical Implications." ISRN Psychiatry, 16, (2012): 600-601.

106 Linda J. Ahrenfeldt, Sören Möller, Karen Andersen-Ranberg, et al. "Religiousness and Health in Europe." Eur J Epidemiol 32, (2017): 921.

107 Chaeyoon Lim and Robert D. Putnam. "Religion, Social Networks and Life Satisfaction," American Sociological Review. 75/6, (2010): 914.

108 Warren J. Sillick, Bruce A. Stevens, Stuart Cathcart, "Religiosity and happiness: A Comparison of the Happiness Levels Between the Religious and the Nonreligious", The Journal of Happiness \& Well-Being, 4/1, (2016): 115.

109 Leslie J. Francis, Yablon, Yaacov B. and Robbins, Mandy. "Religion and Happiness: a Study among Female Undergraduate Students in Israel," International Journal of Jewish Education Research, 7, (2014): 77.

110 Ali Ayten, Gülüşan Göcen, Kenan Sevinç and E. Ensar Öztürk, "Dini Başa Çıkma, Şükür ve Hayat Memnuniyeti İlişkisi,” Din Bilimleri Akademik Araştırma Dergisi, 12/2, (2012): 45; 
memnuniyetinde anlamlı bir yordayıcı olduğu, yine affetme eğiliminin de hayat memnuniyeti üzerinde anlamlı bir etkisinin olduğu anlaşılmıştır. ${ }^{111}$ Kurnaz'ın araştırma sonucunda dini yönelim arttıkça mutluluğun arttığı görülmüştür. ${ }^{112}$ Turan, dindarlık ile hayat memnuniyeti arasında pozitif yönde güçlü bir korelasyon olduğunu rapor etmiştir. ${ }^{113}$ Buna ilaveten yalnızlıkla hayat memnuniyeti arasında da negatif yönde bir ilişkinin olduğunu tespit etmiştir. Buna paralel olarak LeeLee, Ishii-Kuntz'un araştırma sonucuna göre 55 yaş ve üstü 2872 katılımcı ile yapılan araştırma sonucunda yalnızlığın maneviyat üzerinde büyük bir olumsuz etkisinin olduğu; yalnızlık duygularının, arkadaşlarla ve daha az ölçüde komşularla etkileşim yoluyla azaldığı ve maneviyatın arttığı görülmüsştür. ${ }^{114}$

Ahiret ve kader inancına sahip olmanın psikolojik sağlıkta ve mutlu olmada etkili olduğu araştırmalar mevcuttur. ${ }^{115}$ Yaşamda anlam deneyimi ölüm anlayışımızı derinden etkiler. ${ }^{116}$ Ölüm bilinci insana zamanın farkındalığını ve varoluşunun anlamı konusunda sorumluluk bilinci getirir. İnsan yaşamı ölümlülük farkındalığı ile hayat daha zevkli ve yaşanabilir olmaktadır. ${ }^{117}$ Ölümsüzlük inancı bireylerin ölüm kaygısıyla baş etmelerine de yardımcı olur. ${ }^{118} \mathrm{Bu}$ dünyada yaşanılan haksızlıkların karşılığının verileceği, ulaşılamayan isteklerin gerçekleşeceği, ölümün bir son olmadığı ahirete imanın neticesidir. ${ }^{119}$ Kader inancı ise kişinin yaşadığ 1 zorluklar

111 Ali Ayten "Affedicilik ve Din: Affetme Eğilimi ve Dindarlıkla İlişkisi Üzerine Ampirik Bir Araştırma,” M.Ü. Illahiyat Fakültesi Dergisi, 37/2, (2009): 111.

112 Mahmut Kurnaz, "İlk Yetişkinlerde Dini Yönelim-Mutluluk İlişkisi.” (Yüksek Lisans Tezi. Isparta: Süleyman Demirel Üniversitesi, 2015), 125.

113 Yahya Turan, "Yalnızlıkla Başa Çıkma: Yalnızlık, Dini Başa Çıkma, Dindarlık, Hayat Memnuniyeti ve Sosyal Medya Kullanımı”. Cumhuriyet İlahiyat Dergisi 22 (2018 ): 395-434.

114 GR Lee and M. Ishii-Kuntz, "Social Interaction, Loneliness, and Emotional Well-Being among the Elderly.” Res. Aging 9, (1987): 459.

115 Fatma Balcı Arvas, "Öznel İyi-Olma Hali İle Dini İnançlar Arasındaki İlişki Üzerine Bir İnceleme," Uludağ Üniversitesi Ilahiyat Fakültesi Dergisi, 26/2, (2017), 193; Kevin J. Flannelly at all., "Belief in Life After Death and Mental Health-Findings from a National Survey." Journal of Nervous and Mental Disease, 194 /7, (2006): 524; Mojtaba Aghili and G. Venkatesh Kumar. "Relationship between Religious Attitude and Happiness among Professional Employees". Journal of the Indian Academy of Applied Psychology, 34, (2008): 66-69.

116 Ira Byock, “The Meaning and Value of Death", Journal Of Palliatıve Medicıne, 5 /2, (2002): 279.

117 Irvin D., Yalom, "Din ve Psikiyatri” (İstanbul: Turkuvaz Yayıncılık, 2012),57.

118 Murat Yıldız, “Ölüm Kaygısı ve Dindarlık Üzerine Bir Yorum,” Düşünen Siyaset Dergisi, 1 (1999): 108.

119 Abdurrahman Kasapoğlu, Kur'an'da İman Psikolojisi, (İstanbul : Yalnızkurt Yayınları, 1997), 143-147. 
konusunda sabırlı ve umutlu olmasını sağlamaktadır. ${ }^{120}$ Ayrıca Seligman'a göre şükür, mutluluğun en belirgin içsel etkenidir. ${ }^{121} \mathrm{Bu}$ sonuçlar neticesinde dindarlık iyi oluşu, mutluluk ve hayat memnuniyetini olumlu yönde etkilemekte; mutlu olmada şükür, affetme gibi dini değerlerle birlikte ahiret ve kader inancı etkili olmaktadır.

Günümüzde mutlu olmak için insanın yapmak istediklerinin peşinden koşup elde etmesinden çok kişiler arası ilişkilerinde daha yapıcı olması, affedebilmesi, sevebilmesi, iyimser olması gibi içsel yönelime önem verildiği görülmektedir. ${ }^{122}$ Kişinin negatif düşüncelerden arınıp olumlu düşüncelere odaklanması, ${ }^{123}$ çeşitli terapi, egzersiz ve meditasyonlarla kişinin ruhsal açıdan daha dengeli ve kendi özüne yönelik olması ile stresten uzak sakin ve mutlu bir yaşama odaklanılmaktadır. ${ }^{124}$ Gelecekte amaçladığımız şeylerin elde edilmesiyle değil; şimdide gerçekleştirilmeye odaklanılmaktadır. ${ }^{125}$

Din, insana modern çağın mutluluğu elde etme çabasının aksine bu dünyadaki varlıklarla mutlu olunamayacağını ögütlemekte; mutlu olmak için maddiyata yönelen insanın daha mutsuz olacağını belirtmektedir. Ayetlerde ${ }^{126}$ de görüldüğü üzere bu dünyada mutluluk kaynağı olarak algılanan sağlık, eş, çocuklar gibi kişinin elde ettiği tüm maddi varlıklar geçicidir ve yok olmaya mahkûmdur. Buna göre bu dünyada kişilerin sahip olduğu her şey görecelidir. İslam inancına göre onların gerçek sahibi zaten insan değildir. Bu nedenle kişi mutluluğunu çevresel etmenler ile tanımlar ise sahip oldukları veya konumu ortadan kalktığında mutluluğu da kaybolacaktır. O halde bu gibi şeylerle mutlu olunamayacağını idrak eden insan, kendisine yönelerek mutluluğun mülkiyet sahibi olmakta değil; kendi özünde olduğu bilincine ulaşabilir ve gerçek mutluluğun farkına varabilir.

120 Yusuf Kandemir, “Kader İnancının Psikoterapik Açıdan Fonksiyonu” (Yüksek Lisans Tezi, Erzurum: Atatürk Üniversitesi. 2006), 118.

121 Seligman, "Gerçek Mutluluk", 102.

122 Kemal Sayar, Ruh Hali Bireysel Mutluluk Sosyal Mutluluk (İstanbul: Timaş yayınları, 2014), 17-21.

123 Mustafa Çay, Mutsuz Olmak Günahtır (İstanbul: Ganj Yayınları, 2011), 20-43.

124 Nevzat Tarhan, Mutluluk Psikolojisi ve Stresle Başa Çıkma (İstanbul: Timaş Yayınları, 2008), 167-178.

125 Tolle, “A New Earth Awakening”, 71.

126 Servet ve oğullar, dünya hayatının süsüdür; kalıcı olan iyi davranışlar ise rabbinin nezdinde hem sevapça daha hayırlı hem de ümit bağlamaya daha lâyıktır (Kehf/46). Nefsânî arzulara, (özellikle) kadınlara, oğullara, yığın yığın biriktirilmiş altın ve gümüşe, soylu atlara, sağmal hayvanlara ve ekinlere düşkünlük insanlara çekici kılındı. İşte bunlar dünya hayatının geçici menfaatleridir. Hâlbuuki varılacak güzel yer, Allah'ın katındadır (Âl-i İmran/14). 


\section{Sonuç}

Mutluluk, insanı motive eden en güçlü duyguların başında yer almakta; bireylerin yaşamlarını dizayn etmede etkili olmaktadır. Bu nedenle felsefi, psikolojik ve dini alanlarda öncelikli konular arasında yer almaktadır.

Felsefi söylemlere genel olarak bakıldığında filozoflar mutluluğu haz ve erdem açısından değerlendirmişler; bu iki ana düşünce çerçevesinde insanın nasıl mutlu olacağına dair yorum yapmışlardır. Psikologlar ise insanın arzularının farkında olmasından kendisini gerçekleştirmesine; sevmeyi bilmesinden, bir anlam ve amaç edinmeye kadar hedonik/eudomanik yaklaşımlarla ele almışlardır.

Dini açıdan mutlu olmada erdemli olmanın ön planda olduğu görülmektedir. Kişinin kendisini tanıması, özüne yönelmesi; cömert, iffetli, adaletli, dürüst ve affedici olmak gibi erdemlere sahip olması kişiyi bu dünyada mutlu kılacağı gibi ahirette de ödüllendirilmesini sağlayacaktır. Buna göre insanın içsel değişimi, onu her durum ve şartta mutlu kılmayı sağlayabilir.Yapılan dindarlık ve mutluluk ile ilgili araştırma sonuçlarında özellikle ahiret ve kader inancının etkili olması, dinin olumsuz yaşantılara karşı bir teselli olduğunu ve hayata anlam kattığını göstermektedir. Ayrıca dini grupların kişileri mutlu ettiği; dini açıdan önemli olan affetme, şükür gibi erdemlerin kişinin mutlu olmasını sağladığı görülmüştür. Buna göre bir dine inanıp onun gereğini yerine getirme, insanların yaşadıkları maddi ve manevi sıkıntılarla baş etmelerini sağlayabilmekte ve mutsuzluk sebebi olarak görülen şeylerin üstesinden gelme imkânı sunabilmektedir.

İslam ahlakçılarına göre ahlaklı ve bilgece bir yaşam kişiye mutluluk getirecektir. Tasavvufta ise gerçek mutluluk kişinin kendisini tanımasıyla olacaktır. İnsan maddi ihtiyaçların ötesine, kendisine yöneldiğinde mutluluk doğal olarak ortaya çıkabilecektir. Son zamanlarda psikolojide de mutlu olmak için çabalamak yerine kişinin kendisine yönelmesinden ve erdemlerden bahsedilmektedir. Ancak mutluluk dinde, psikolojideki gibi bir arayış veya bir hedef olmadığı gibi mutluluğun zamansal veya durumsal açıdan sınırı olmadığından bahsedebiliriz. Dinin mutluluk anlayışının herhangi bir şarta bağlı olmaması, öbür dünyada mükâfat beklentisi de dahil olmak üzere kişiyi her şeyden özgür kılabilir.

Sonuç olarak kişinin kendisini bilmesi dini, mistik ve hatta günümüz bazı güncel psikoloji çalışmaları açısından mutlu olmada ortak bir mahiyet arz etmektedir. Kişinin varlığının bilincinde olması gerçek mutluluğa ermesiyle birlikte onu doğal olarak erdemli davranışlara da yönlendirebilir. Bu hayatta var olan herşeyin yok olmaya mahkum olduğunu idrak eden insan geçici mutluluk veya mutsuzluğa odaklanmak yerine kendisine yönelebilir. 
$\mathrm{Bu}$ araştırma mutluluk kavramını felsefi, psikolojik ve dini açıdan ele almıştır. İleriki araştırmalarda mutlulukla ilgili dini ve dünyevi alg1 ele alınarak ampirik çalışmaların yapılması bireylerde mutluluk algısını kavramak açısından önemlidir.

Hakem Değerlendirmesi: Dış bağımsız.

Çıkar Çatışması: Yazar çıkar çatışması bildirmemiştir.

Finansal Destek: Yazar bu çalışma için finansal destek almadığını beyan etmiştir.

Peer-review: Externally peer-reviewed.

Conflict of Interest: The author has no conflict of interest to declare.

Grant Support: The author declared that this study has received no financial support.

\section{Kaynakça/Referencess}

Abdel-Khalek, Ahmed M. "Happiness, Health, and Religiosity: Significant Associations Among Lebanese Adolescents." Mental Health Religion \& Culture 17/1, (2014), 1-11.

Acar, Nilüfer V., Yıldırım, İbrahim ve Ergene, Tuncay. "Bireylerin Dindarlık Düzeylerinin Bazı Değişkenler Açısından İncelenmesi”, Hacettepe Üniversitesi Eğitim Fakültesi Dergisi, 12, (1996), 45-56.

Acaboğa, Asiye. "Din Mutluluk İlişkisi.” Yüksek Lisans Tezi. Kahramanmaraş: Sütçü İmam Üniversitesi Sosyal Bilimler Enstitüsü, 2007.

Aghili, Mojtaba, and Kumar, G. Venkatesh. "Relationship between Religious Attitude and Happiness among Professional Employees", Journal of the Indian Academy of Applied Psychology, 34, (2008), 66-69.

Ahrenfeldt, Linda .J., Möller, Sören., Andersen-Ranberg, Karen et al. "Religiousness and Health in Europe.” Eur J Epidemiol 32, (2017), 921-929.

Akarsu, Bedia. Ahlâk Öğretileri 1 Mutluluk Ahlakı. İstanbul: İstanbul Üniversitesi Edebiyat Fakültesi Yayınları, 1965.

Alain, Chartier. Mutlu Olma Sanatı. İstanbul: Kaknüs Yayınları, 1998.

Arıcı, Havva Yalvaç. “Kur’an’da Mutluluk Kavramı ve Eğitimi.” Doktora Tezi. İstanbul: İstanbul Üniversitesi Sosyal Bilimler Enstitüsü, 2019.

Aristoteles, Nikomakos'a Etik, Çev. Furkan Akderin, İstanbul: Say Yayınları, 2014.

Armaner, Neda. Din Psikolojisine Giriş. Ankara: Ayyıldız Matbaası, 1980.

Arvas, Fatma Balc1. "Psikolojide ve İslam Düşünce Geleneğinde Mutluluk Kavramı: Karşılaştırmalı Bir Çalışma.” İnsan ve Toplum Bilimleri Araştırmaları Dergisi. 6/4, (2017), 109-128.

Arvas, Fatma Balcı. "Öznel İyi-Olma Hali İle Dini İnançlar Arasındaki İlişki Üzerine Bir İnceleme.” Uludağ Üniversitesi İlahiyat Fakültesi Dergisi, 26/2, (2017), 166-201.

Attâs, Nakîb, "İslam'da Mutluluğun Anlamı ve Tecrübesi.” Çev. Şaban Ali Düzgün, Kelam Araştırmaları. 9/2, (2011), 219-238.

Aydemir, Rüveyda Efdal. “Dindarlık ve Mutluluk İlişkisi (İlk Yetişkinlik Dönemi).” Yüksek Lisans Tezi, Çanakkale: Çanakkale Onsekiz Mart Üniversitesi Sosyal Bilimler Enstitüsü, 2008. 
Ayten, Ali. "Din ve Sağlı: Bireysel Dindarlık, Sağlık Davranışları ve Hayat Memnuniyeti İlişkisi Üzerine Bir Araştırma.” Dinbilimleri Akademik Araştırma Dergisi. 13/3, (2013), 7-31.

Ayten, Ali. "Affedicilik ve Din: Affetme Eğilimi ve Dindarlıkla İlişkisi Üzerine Ampirik Bir Araştırma”. M.Ü. İlahiyat Fakültesi Dergisi, 37/2, (2009), 111-128.

Ayten, Ali, Göcen, Gülüşan, Sevinç, Kenan ve Öztürk, E. Ensar, "Dini Başa Çıkma, Şükür ve Hayat Memnuniyeti İlişkisi.” Din Bilimleri Akademik Araştırma Dergisi. 12/2, (2012), 45-79.

Ayten, Ali ve Tura, Hatice. “Affetme Ve Dindarlık, Hayat Memnuniyetini Nasıl Destekler?” Íslâmî Ilimler Dergisi, 12, 12/3, (2017), 27-54.

Ayten, Ali ve Ferhan, Hamza. "Forgiveness, Religiousness, and Life Satisfaction: An Empirical Study on Turkish and Jordanian University Students." Spiritual Psychology and Counseling, $1 / 1,(2016), 75-84$.

Ayten, Ali ve Gashi, Fehim. "Affetme ve Hayat Memnuniyeti Üzerine Karşılaştırmalı Bir Araştırma.” Balkan Araştırmaları Dergisi, 3/2, (2012), 11-36.

Ayten, Ali \& Sezai Korkmaz, "The Relationships Between Religiosity, Prosociality, Satisfaction With Life And Generalised Anxiety: A Study On Turkish Muslims," Mental Health Religion \& Culture, (2020), 980-993.

Bahadır, Abdulkerim. "Modernitenin Yıkıcı Etkileri Karşısında Savunmasız İnsan.” Necmettin Erbakan Üniversitesi IIlahiyat Fakültesi Dergisi 13, (2002) 129-142.

Baasher, T.A., "İslam and Mental Health.” Eastern Mediterranean Health Journal, 7/3, (2001), 372-376.

Bilgen, Sümeyye. "Hadislerde Mutluluk ve Mutsuzluk Sebepleri.” Yüksek Lisans Tezi. Isparta: Süleyman Demirel Üniversitesi Sosyal Bilimler Enstitüsü, 2018.

Bircan, Hasan Hüseyin. İslam Felsefesinde Mutluluk. İstanbul: İz Yayınc1lık, 2001.

Bircan, H. Hüseyin. "İslam Ahlak Felsefesinde 'En Yüce Gaye' Kavramı ve Ahlaki Değerlerin Belirlenimi." İslami Araştırmalar Dergisi, 16/3 (2004), 422-429.

Bono, Giacomo, McCullough, Michael E. and Root, Lindsey M. "Forgiveness, Feeling Connected to Others, and Well-Being: Two Longitudinal Studies." Personality and Social Psychology Bulletin, 34, (2008), 182-195.

Borgna, Eugenio. Ruhun Yalnızlığı. Çev. Meryem Mine Çilingiroğlu. İstanbul: Yapı Kredi Yayınları, 2014.

Byock, Ira. “The Meaning and Value of Death”. Journal Of Palliatıve Medicıne, 5/2, (2002), 279-287.

Cambridge Dictionary. "Well Being," 13 Nisan 2020, https://dictionary.cambridge.org/tr/ $\mathrm{s} \% \mathrm{C} 3 \% \mathrm{~B} 6 \mathrm{zl} \% \mathrm{C} 3 \% \mathrm{BCk} /$ ingilizce/well-being.

Camfield, Laura, and Skevington, Suzanne M. "On Subjective Well-Being and Quality of Life." Journal of Health Psychology, 13/6, (2008), 764-775.

Carrel, Alexis. İnsan Denen Meçhul. İstanbul: Hayat Yayınları,1997.

Cücü,Taner, İslam'da Mutluluk Prensibi. İstanbul: Otağ Yayınları,1978.

Çağrıcı, Mustafa. “Kindi’nin Def'ul - Ahzan Adlı Risalesi, Kaynakları ve Tesirleri”. Ístanbul: Marmara Üniversitesi İlahiyat Fakültesi Dergisi. (1995), 221-241.

Classen, Albrecht. "Mystical Visions and Spiritual Health -Medieval Mysticism as a Platform For The Exploraton of Human Spirituality and Happiness". Studies in Spirituality, 25, (2015).

Coştu, Yakup. "Dine Normatif ve Popüler Yaklaşım Bir Dini Yönelim Ölçeği Denemesi”. Hitit Üniversitesi Ilahiyat Fakültesi Dergisi, 1, 8/15, (2009), 119-139. 
Csikszentmihalyi, Mihaly. Akış- Mutluluk Bilimi. Çevirmen: Barış Satılmış, İstanbul: Buzdağı Yayınc1lik, 2017.

Çay, Mustafa. Mutsuz Olmak Günahtır. İstanbul: Ganj Yayınları, 2011.

Deci, Edward, and Ryan, Richard. "Hedonia, Eudaimonia and Well-Being: An Introduction”. Journal of Happiness Studies, 9, (2008), 1-11.

Demirkol, Murat. "İslam Ahlak Düşüncesinin Gelişiminde Filozofların Katkısı”. Eskiyeni 28, (2014), 67-95.

Diener, Ed, Emmons, Robert A., Larsen, Randy J., and Griffin, Sharon. "The Satisfaction With Life Scale." Journal of Personality Assessment, 49,1,1985, 71-75.

Diener Ed, and Diener, Marissa. "Cross-Cultural Correlates of Life Satisfaction and Self-Esteem". J. Pers. Soc. Psychol. 68, (1995), 653-663.

Diş, Sebile Başok. "Bir Dayatma Halini Alan Mutluluk Talebi”. Temaşa, 8, (2018).

Duman, Zeki. “Tüketimci Kapitalizmin ve Tüketim Kültürünün Eleştirisi,” Sosyoloji Dergisi, 33, (2016), 15-36.

Emmons Robert A. "Personal Strivings: an Approach to Personality and Subjective Wellbeing". $J$. Pers. Soc. Psychol. 51, (1986),1058-6.

Flannelly, Kevin J. at all. (2006). "Belief in Life After Death and Mental Health-Findings from a National Survey." Journal of Nervous and Mental Disease, 194, 7, 2006, 524-529.

Francis, Leslie J., Yablon, Yaacov B. and Robbins, Mandy. "Religion and Happiness: a Study among Female Undergraduate Students in Israel". International Journal of Jewish Education Research, 7, (2014), 77-92.

Frankl, Victor. İnsanın Anlam Arayışı. İstanbul: Öteki yayınları, 2000.

Freud, Sigmund. Mutluluk Dediğimiz Şey Aforizmalar Çeviren Peren Demirel. İstanbul: Aylak Adam Yayınları, 2017.

Freud, Sigmund. Uygarlık, Din ve Toplum, Ankara: Öteki Yayınevi, 1995.

Fromm, Erich. Psikanaliz ve Din. Çev. Aydın Arıtan. İstanbul: Arıtan Yayınları, 1993.

Fromm, Erich. Sahip Olmak ya da Olmak. Çev. Aydın Arıtan. İstanbul: Arıtan Yayınları, 1994.

Fromm, Erich. Erdem ve Mutluluk. Çev. Ayda Yörükan. Ankara: İş Bankası Yayınları, 1995.

Gazâlî, Kimyâ-yı Saâdet-Mutluluk ve Saadet Yolu, Çev. Ali Arslan, İstanbul: Merve Yayınları, 2004.

Gencer, Nevzat. "Hemodiyaliz Hastalarında Dindarlık ve Öznel İyi Oluş.” Doktora Tezi, Çorum: Hitit Üniversitesi Sosyal Bilimler Enstitüsü, 2019.

Genç, Ernur ve Coşkun, Tuba. "Muhafazakârlık ve Türkiye Muhafazakârlarının Bazı Halleri.” Niğde Üniversitesi İktisadi ve İdari Bilimler Fakültesi Dergisi. 8/1, (2015), 27-40.

Gezenler, Ayşegül. “Orta Yetişkinlik Dönemi Dindarlık ve Mutluluk İlişkisi.” Yüksek Lisans Tezi, Samsun: Ondokuz Mayıs Ünivesitesi Sosyal Bilimler Enstitüsü, 2019.

Göcen, Gülüşan. "Pozitif Psikoloji Düzleminde Psikolojik İyi Olma ve Dini Yönelim İlişkisi: Yetişkinler Üzerine Bir Araştırma.” Toplum Bilimleri, 7/13, 2013.

Günay, Ünver. Dindarlığın Sosyolojisi. Dindarlığın Sosyo-Psikolojisi içinde, Adana: Karahan Kitabevi, 2006.

Güngör, Erol. İslam Tasavvufu'nun Meseleleri. İstanbul: Ötüken Yayınları, 1982.

Hallahmi, Benjamin Beit, and Argyle, Michael. "Dindarlığın Etkileri 1" (Çev. Adem Şahin), Selçuk Üniversitesi İlahiyat Fakültesi Dergisi, Konya, 10, (2000), 453- 477. 
Harold G. Koenig. "Religion, Spirituality, and Health: The Research and Clinical Implications". ISRN Psychiatry, 16, (2012), 1-33.

Horney, Karen. Çağımızın Tedirgin İnsanı. Çev. Ayda Yörükan, İstanbul: Tur Yayınları, 1980.

Hökelekli, Hayati. Din Psikolojisi. Ankara: Türkiye Diyanet Vakfı Yayınları, 1993.

Hume, David. Din Üstüne. Çev. Mete Tunçay. İstanbul: İmge yayınları, 1995.

Johnstone, Ronald L. Religion in Society: A Sociology of Religion. New Jersey: Pearson/Prentice Hall, 1982.

J. Van Dyke, Cydney and Elias, Maurice. "How Forgiveness, Purpose, and Religiosity are Related to the Mental Health and Well-being of Youth: A Review of theLiterature." Mental Health, Religion \& Culture, 10/4, (2007), 395-415.

Jung, Carl Gustav. Man and His Symbols, Concieved and Edited By Carl Gustav Jung. New York: Anchor Press Book, 1964.

Kaba, İlker, Erol, Murat ve Güeç. Kadir. "Yetişkin Yaşam Doyumu Ölçeğinin Geliştirilmesi”. Anadolu Üniversitesi Sosyal Bilimler Dergisi. (2017), 1-14.

Kandemir, Yusuf. “Kader İnancının Psikoterapik Açıdan Fonksiyonu.” Yüksek Lisans Tezi. Erzurum: Atatürk Üniversitesi, 2006.

Kangal, Ayça "Mutluluk Üzerine Kavramsal Bir Değerlendirme ve Türk Hane Halkı İçin Bazı Sonuçlar.” Elektronik Sosyal Bilimler Dergisi, 12/44, (2013), 214- 233.

Kar, Sait. "Din, Aydınlanma ve Eleştirisi”, Atatürk Üniversitesi Illahiyat Fakültesi Dergisi, 42, (2014) 173-192.

Karakaya, Filiz Toprak, ve Uysal, Enver. “Fârâbî'de ‘İyi, Yetkinlik ve Mutluluk' Kavramları Işığında PDR Hizmetlerine Farklı Bir Yaklaşım”. Sinop Üniversitesi Sosyal Bilimler Dergisi, 3/1, (2019), 191-208.

Kasapoğlu, Abdurrahman. Kur'an'da İman Psikolojisi. İstanbul : Yalnızkurt Yayınları, 1997.

Kaya, Özgür Salih, ve Fatih Orçan. "Mutluluğun Empati, Affetme ve Yaşam Doyumu Arasındaki Arac1 Rolü: Bir Yol Analizi”. Bolu Abant İzzet Baysal Üniversitesi Eğitim Fakültesi Dergisi, 19/2, (2019), 540-554.

Kayıklık, Hasan. Tasavvuf Psikolojisi. Akçağ Yayınları, 2009.

Keleş, Ali. "Din Görevlilerinde Dindarlık ve Mutluluk Arasındaki İlişki (Sivas Örneği)." Yüksek Lisans Tezi, Sivas: Sivas Cumhuriyet Üniversitesi, 2019.

Khirizad, Babak. "Transpersonel Psikolojide Affetmek.” Doktora Tezi. Ankara: Ankara Üniversitesi Sosyal Bilimler Fakültesi, 2017.

Kınalızâde Ali Efendi, Ahlâk-ı Alâ̂, Hazırlayan Hüseyin Algül, İstanbul: Tercüman 1001 Temel Eser, t.y.

Kierkegaard, Soren. Ölümcül Hastalık Umutsuzluk. Çev; Mehmet Mukadder. Ankara: Doğu Batı Yayınları, 2004.

Koenig, Harold G., and Larson, David B. "Religion and Mental Health : Evidence for An Association," International Review of Psychiatry 13/2 (2001), 67-78.

Koenig, Harold G. "Religion, Spirituality, and Health: The Research and Clinical Implications." ISRN Psychiatry, 16, (2012), 600-601.

Krause, Neal. "Religious Meaning and Subjective Well-Being in Late Life". The Journals of Gerontology. 58/3, (2003), 160-170.

Kurnaz, Mahmut. "İlk Yetişkinlerde Dini Yönelim-Mutluluk İlişkisi.” Yüksek Lisans Tezi. Isparta: Süleyman Demirel Üniversitesi, 2015. 
Kur'ân-ı Kerîm Meâli, çev. Halil Altuntaş \& Muzaffer Şahin. Ankara: Diyanet İşleri Başkanlığ1 Yayınları, 2011.

Lama, Dalai, and Howard C. Cutler, M.D. Mutluluk Sanatı. İstanbul: Dharma Yayınları, 2000.

Levin, Jeffrey S., and Taylor, Robert Joseph. "Panel Analyses of Religious Involvement and WellBeing in African Americans: Contemporaneous vs. Longitudinal Effects." Journal for the Scientific Study of Religion, 37/4, (1998), 695-709.

Lim, Chaeyoon, and Putnam. Robert D. "Religion. "Social Networks and Life Satisfaction." American Sociological Review. 75/6, (2010), 914-933.

Maslow, Abraham. İnsan Olmanın Psikolojisi. Çev. Okhan Gündüz, İstanbul: Kuraldışı Yayınevi, 2001.

Marar, Ziyad. Mutluluk Paradoksu Özgürlük ve Onaylanma. Çev. Serpil Çağlayan, İstanbul: Kitap Yayınevi, 2004.

Martela, Frank, Greve, Ben, Rothstein, Bo and Saari, Juho. "The Nordic Exceptionalism: What Explains Why the Nordic Countries are Constantly Among the Happiest in the World." in 2020 World Happiness Report, Edit: Editors: John F. Helliwell and others, A publication of the Sustainable Development Solutions Network, 2020. Erişim tarihi 23.03.2020. https://happiness-report. s3.amazonaws.com/2020/WHR20.pdf.

Martin, Faith. Psychology, Religion and Development: a Literature Review. Working Paper. UK: University of Birmingham, 2008.

Martin, Mike W. "Happiness and Virtue in Positive Psychology." Journal for the Theory of Social Behaviour, 37/1, 0021-8308, (2007), 89-103.

May, Rollo. Kendini Arayan İnsan. Çev. Ayşe Karpat. İstanbul: Kuraldışı Yayınları, 1997.

Nielsen, Michael E., "Din ve Mutluluk,” Bilimname XXXIII, 1, (2017), 141-144.

Ocak, Hasan. "Kınalızâde Ali Efendi’de Mutluluk Ahlakı Kavramının Felsefi Temelleri”, I Ĭdır Üniversitesi Sosyal Bilimler Dergisi 1, (2012), 115-136.

Özasma, Halil İbrahim. "Pozitif Psikoloji ve İslam Düşünürlerinde Erdemler.” Yüksek Lisans Tezi. Ankara Üniversitesi, 2016.

Öztürk, Latif, Meral, Gürkan ve Serhat Yılmaz. "Lisans Öğrencilerinin Mutluluk ve Dindarlık İlişkisi (Kırıkkale Üniversitesi Örneği)” Akademik Yaklaşımlar Dergisi. 8/1 (2014), 35-36.

Park, Nansook, Christopher, Peterson, and Runch Willibald. "Orientations to Happiness and Life Satisfaction in Twenty-Seven Nations.” The Journal of Positive Psychology, 4/4, (2009), 273-279.

Park, Crystal L. "Religion as a Meaning-Making Framework in Coping with Life Stress.” Journal of Social Issues 61(4), (2005), 707 - 729.

Peterson, Christopher, Park, Nansook, and Martin E.P. Seligman "Orientations to Happiness and Lise Satisfaction: The Full Life Versus The Empty Life". Journal of Happiness Studies, 6, (2005), 25-41.

Pew Research Center. Religion's Relationship to Happiness, Civic Engagement and Health Around the World, 2019.

https://www.pewforum.org/2019/01/31/religions-relationship-to-happiness-civic-engagement-andhealth-around-the-world/ Erişim: 9.1.2020.

Platon, Menon, Çeviren Furkan Akderin. İstanbul: Say Yayınları, 2013.

Platon, Phaidon, Çeviren Furkan Akderin. İstanbul: Say Yayınları,2015.

Ryan, Richard, and Deci, Edward. "On Happiness and Human Potentials: A Review Of Researchon Hedonic and Eudaimonic Well-Being.” Annu. Rev. Psychology. 52, (2001), 141-166. 
Ryff Carol D. "In the Eye of the Beholder: Views of Psychological Well-Being Among Middle-Aged and Older Adults." Psychol. Aging 4, (1989), 195-210

Sayar, Kemal. Ruh Hali Bireysel Mutluluk Sosyal Mutluluk. İstanbul: Timaş Yayınları, 2014.

Schopenhauer, Arthur. Hayatın Anlamı. İstanbul: Say Yayınları, 2008.

Schmutte Pamela S., and Carol D. Ryff. "Personality and Well-Being: Reexamining Methods and Meanings". J. Pers. Soc. Psychol. 73, (1997), 549-59.

Seligman, Martin E.P.. Gerçek Mutluluk. Çev. Semra Kunt Akbaş. Ankara: HYB Yayınları, 2002.

Seligman, Martin E.P. Öğrenilmiş Iyimserlik. Çev. Semra Kunt Akbaş. Ankara: Boylam Psikiyatri Enstitüsü Yayınları, 2007.

Seligman, Martin E. P., Mihalyi Csikszentmihalyi. "Positive Psychology: An Introduction.” American Psychologist, 55 (1), (2000), 5-14.

Sevindik, Durmuş. “Orta Yaş Dönemi Bireylerde Dindarlık Mutluluk İlişkisi: (Denizli Örneği)." Yüksek Lisans Tezi. Isparta: Süleyman Demirel Üniversitesi Sosyal Bilimler Üniversitesi, 2015.

Sillick, Warren J., Bruce A. Stevens and Stuart Cathcart. "Religiosity and Happiness: A Comparison of the Happiness Levels Between the Religious and the Nonreligious." The Journal of Happiness \& Well-Being, 4/1, (2016), 115-127.

Sönmez, Alper, ve Özlem Altınsu Sönmez. "Life Satisfaction and Happiness with Regard to Human Capital and Religiosity in Turkey.” Bingöl Üniversitesi Sosyal Bilimler Enstitüsü Dergisi, 8/16, (2018), 219-234.

Spira, Rupert. "Happiness Is Knowing Our Own Being." 13.04.2020. https://non-duality.rupertspira. com/read/happiness_is_knowing_our_own_being Erişim 4.04.2020.

Tamtürk, Bayram. "Farabi’nin Mutluluk Anlayışı." Yüksek Lisans Tezi. Ankara: Gazi Üniversitesi Sosyal Bilimler Enstitüsü, 2006.

Tarhan, Nevzat. Mutluluk Psikolojisi ve Stresle Başa Çıkma. İstanbul: Timaş Yayınları, 2008.

Taş, Nurten. “Tıp ve İlahiyat Fakültesi Öğrencilerinde Batıl İnanç, Dindarlık ve Mutluluk İlişkisi.” Yüksek Lisans Tezi. Çanakkale: Çanakkale On Sekiz Mart Üniversitesi Sosyal Bilimler Enstitüsü, 2019.

Tolle, Echart. A New Earth Awakening is Your Lifes Purpose. Usa: Penguin Group, 2008.

Turan Yahya. "Yalnızlıkla Başa Çıkma: Yalnızlık, Dini Başa Çıkma, Dindarlık, Hayat Memnuniyeti ve Sosyal Medya Kullanımı”. Cumhuriyet İlahiyat Dergisi 22 (2018 ), 395-434.

Tuzcuoğlu, Nuran. “Kant’ta Ödev Ahlakının Temellendirilişi.” Yüksek Lisans Tezi. İstanbul: Marmra Üniversitesi Sosyal Bilimler Enstitüsü, 2008.

TÜIK. ”Yaşam Memnuniyeti Araştırması.” 2019, Erişim 23.02.2020. file://C:/Users/hasan/AppData/ Local/Temp/Temp1_Yaşam_Memnuniyeti_Araştırmas1_17.02.2020\%20(1).zip/Haber_Bulteni.pdf.

Waterman Alan S. "Two Conceptions of Happiness: Contrasts of Personal Expressiveness (Eudaimonia) and Hedonic Enjoyment”. J. Pers. Soc. Psychol. 64, (1993), 678-91.

WHO, "World Mental Health Day: Depression: A Global Crisis." Geneva, World Health Organization, 2012.

Wilcox, Lynn. Sufism and Psychology. Chicago: Abjad Book Designers \& Builders, 1995.

Wood, Alex M., Stephen Joseph, and P. Alex Linley. "Coping Style as a Psychological Resource of Grateful People.” Journal of Social and Clinical Psychology, 26, (2007), 1108-1125.

Veenhoven, Ruut. "Happiness: Also Known as 'Life-Satisfaction' and 'Subjective Well-Being””, In: Kenneth C. Land, Alex C. Michalos, and M. Joseph Sirgy (Eds.) Handbook of Social Indicators and Quality of Life Research. Dordrecht, Netherlands: Springer Publishers. 2012. 
Veenhoven, Ruut. "The Study Of Life Satisfaction.” In W. E. Saris, R. Veenhoven, A. C. Scherpenzeel, \& B. Bunting (Eds.), A Comparative Study Of Satisfaction With Life In Europe. Budapest: EOtvOs University Press, 1996, 11-48.

Yahya Bin Adî, Tahzibü’l-Ahlâk, Çeviren Harun Kuşlu, İstanbul: Türkiye Yazma Eserler Kurumu Başkanlığ $1,2013$.

Yalom, Irvin D., Din ve Psikiyatri. İstanbul: Turkuvaz Yayıncılık, 2012.

Yanıklar, Cengiz. "Tüketim Kültürü, Kapitalizm ve İnsan İhtiyaçları Arasındaki İlişki Üzerine Bir Tartışma " C.Ü. Sosyal Bilimler Dergisi, 34 /1 (2010), 25-32.

Yapıcı, Asım. Ruh Sağlığı ve Din. Adana: Karahan yayınları, 2007.

Yıldız, Murat. “Ölüm Kaygısı ve Dindarlık Üzerine Bir Yorum.” Düşünen Siyaset Dergisi, 1 (1999), 108.

Yorulmaz, Özlem. "Relationship Between Religiosity and Happiness in Turkey: Are Religious People Happier?" Çankırı Karatekin Üniversitesi İktisadi ve İdari Bilimler Fakültesi Dergisi, 6/1, (2016), 801-818.

Yıldırım, Emine Taşçi. İslam Felsefesinde İnayet: İbn Sînâ Örneği, Ankara: Gece Kitaplığı, 2020. 